\title{
U-Pb LA-ICP-MS GEOCHRONOLOGY AND GEOCHEMISTRY OF JURASSIC VOLCANIC AND PLUTONIC ROCKS FROM THE PUTUMAYO REGION (SOUTHERN COLOMBIA): TECTONIC SETTING AND REGIONAL CORRELATIONS
}

\author{
Sebastián Zapata ${ }^{1,2}$; Agustín Cardona ${ }^{2}$; Carlos Jaramillo ${ }^{3}$; Víctor Valencia ${ }^{4}$; Jeff Vervoort ${ }^{4}$ \\ DOI: http://dx.doi.org/10.18273/revbol.v38n2-2016001 @) (1) @ \\ Forma de citar: Zapata., S., Cardona, A., Jaramillo, C., Valencia, V., and Vervoort, J. 2016. U-Pb LA-ICP-MS \\ geochronology and geochemistry of Jurassic volcanic and plutonic rocks from the Putumayo region (southern \\ Colombia): tectonic setting and regional correlations. Boletín de Geología, 38(2): 21-38.
}

\begin{abstract}
New field data, geochemical analyses and zircon U-Pb LA-ICP MS data were obtained on plutonic and volcanic rocks of the Mocoa Batholith and Saldaña Formation in southern Colombia Putumayo region. Results suggest that the plutonic and volcanic activities are closely related to a common magmatic history. This volcano-plutonic association presents a well-defined LILE and LREE enrichment and negative $\mathrm{Nb}$ and Ti negative anomalies characteristic of continental magmatic arcs. Volcanic and plutonic rocks crystallized between 180-186 Ma as revealed by $\mathrm{U}-\mathrm{Pb}$ zircon geochronology. The magmatic activity is temporally and chemically correlatable with other magmatic arc exposures in Colombia and Ecuador. These units may represent the remnants of a single belt which includes several units from $4^{\circ} \mathrm{N}$ in Colombia and $5^{\circ} \mathrm{S}$ in Ecuador. This arc is related to the widespread Jurassic continental magmatic arc setting that characterized the continental margins of the Americas after Pangea break-up.
\end{abstract}

Keywords: Jurassic, continental arc, geochronology, geochemistry.

\section{GEOQUIMICA Y GEOCRONOLOGIA U-Pb LA-ICP-MS DE UNIDADES VOLCÁNICAS Y PLUTÓNICAS DEL JURÁSICO EN LA REGIÓN DEL PUTUMAYO (SUR DE COLOMBIA): IMPLICACIONES TECTONICAS Y CORRELACIONES REGIONALES}

\section{RESUMEN}

Nuevos datos de campo, análisis geoquímicos y U-Pb LA-ICP MS en circón fueron obtenidos en rocas plutónicas y volcánicas en el Batolito de Mocoa y la Formación Saldaña, en el departamento de Putumayo en el sur de Colombia. Los resultados sugieren que el volcanismo y plutonismo que compartieron la misma historia de evolución magmática. Esta asociación vulcano-plutónica muestra enriquecimientos de LILE y LREE acompañado de anomalías negativas de $\mathrm{Nb}$ y Ti característico de arcos continentales. Rocas volcánicas y plutónicas de este arco continental cristalizaron entre 180 y 186 Ma como lo indica la geocronología U-Pb en circón. La actividad magmática esta temporal y geoquímicamente correlacionada con otro arco magmático expuesto en Colombia y Ecuador. Estas unidades pueden representar los remanentes de un solo cinturón que incluye varias unidades entre $\operatorname{los} 4^{\circ} \mathrm{N}$ en Colombia y $5^{\circ} \mathrm{S}$ en Ecuador. Este arco está relacionado a un cinturón magmático Jurásico fragmentado, que caracterizo las márgenes continentales de las Américas luego de la ruptura del súper continente Pangea.

Palabras clave: Jurásico, arco continental, geocronología, geoquímica.

\footnotetext{
${ }^{1}$ Corporación Geológica Ares, Calle 57 No. 23-09 of 202, Bogotá, Colombia. szapatah@gmail.com

${ }^{2}$ Departamento de Procesos y Energía, Universidad Nacional de Colombia, Sede Medellín, Colombia

${ }^{3}$ Smithsonian Tropical Research Institute, Panama, Panama

${ }^{4}$ School of Earth and Environmental Sciences, Washington State University, Pullman WA, USA
} 


\section{INTRODUCTION}

Jurassic magmatism is one of the most extensively exposed igneous record in the Colombian Andes (FIGURE 1). It includes different volcanic sequences and batholith bodies limited as fault bounded blocks along most of the Eastern Andes (Aspden et al., 1987). Different tectonic environments have been proposed to explain this major Jurassic province in the Northern Andes: (1) continental arc magmatism associated to back-arc basin formation (Aspden et al., 1987; Bustamante et al., 2010; Pindell and Tabbutt, 1995; Sarmiento et al., 2006; Spikings et al., 2014; Van der Lelij et al., 2015); (2) rift related setting associated with the Pangea breaking and the development of Proto-Caribbean sea between North and South America (Cediel et al., 2000; Cediel et al., 2003; Jaillard et al.,
1990). A major difficulty for the understanding of this tectonic scenario is the existence of late Mesozoic and early Cenozoic terrain translation along the Jurassic continental margin, which modified the latitudinal position of the Jurassic magmatic domains (Bayona, et al., 2006).

In this contribution we present new U-Pb LA-ICPMS zircon geochronology data and geochemistry reconnaissance from the Mocoa Batholith and Saldaña Formation in southern Colombia. The new results confirm the existence of a Middle Jurassic basaltic to rhyolitic arc magmatism, where volcanic and plutonic activity was genetically related. The results can be correlated with the evolution of other Jurassic segments of the Colombian Andes.

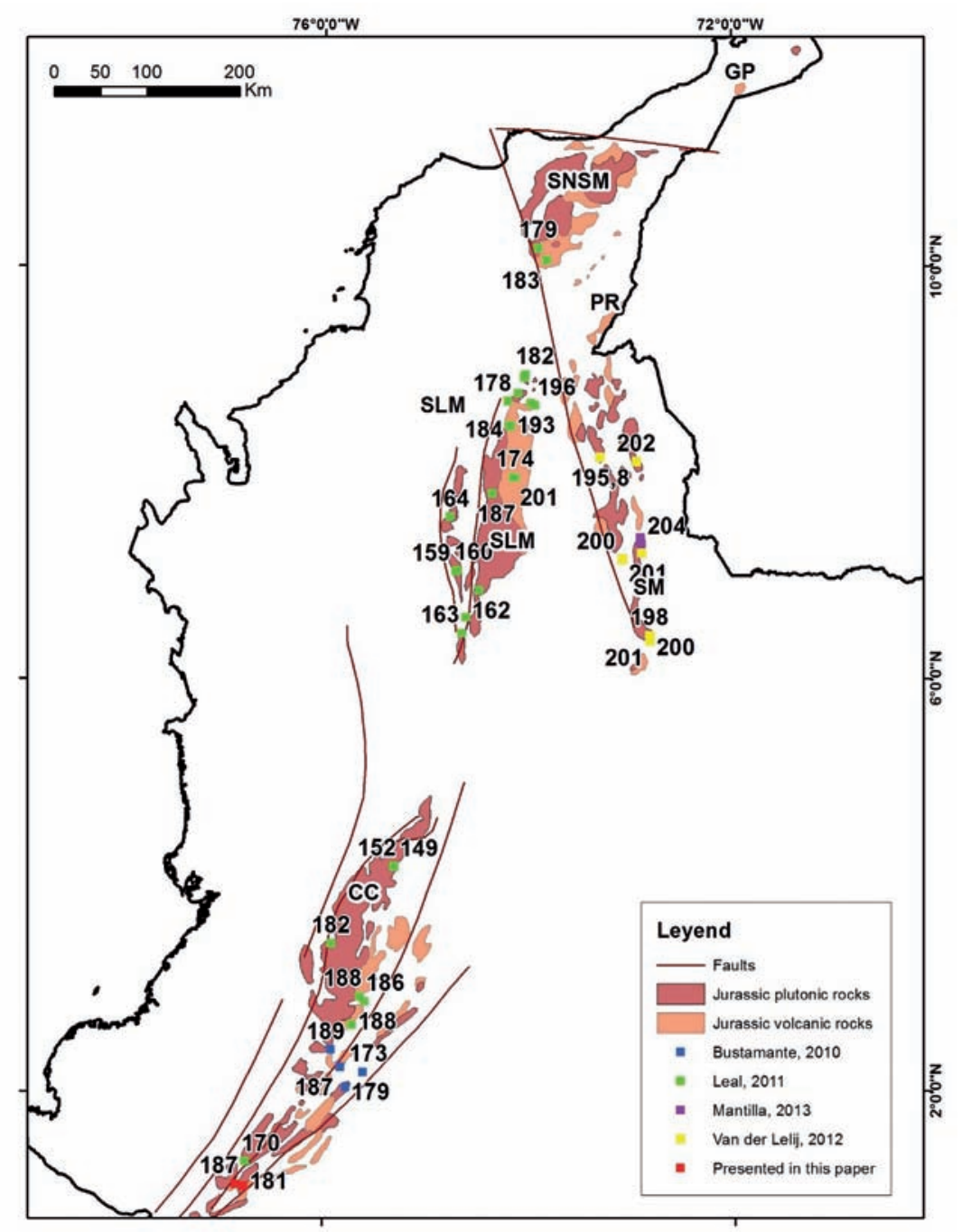

FIGURE 1. Jurassic magmatic rocks from the Colombian Andes and study area location. SNSM: Sierra Nevada de Santa Marta; GP: Guajira Peninsula; PR: Perijá Range; SLM: Serranía de San Lucas Massif; SM: Santander Massif and CC.: Central Cordillera. The dots represent other correlationable U-Pb Jurassic ages. 


\section{GEOLOGICAL SETTING}

The northwestern margin of South America is composed of different structural blocks bounded by major regional faults. This structural complexity reflects several episodes of Mezo-Cenozoic oceanic terrane accretion, continental arc growth and strike translation of paraautochthonous continental terranes (Bayona et al., 2006; Bayona et al., 2010; Escalona and Mann, 2010; Montes et al., 2010; Pindell et al., 1998; Pindell et al., 2005; Spikings et al., 2014; Spikings et al., 2005; Toussaint and Restrepo, 1996; Villagómez et al., 2011; Villagómez and Spikings, 2013).

In Colombia, the northern Andes include three main ranges composed by different litho-stratigraphic units (FIGURE 1). The Western Cordillera comprises allochthonous sequences of mafic volcanic rocks formed in island arc and plateau tectonic setting, with associated Upper Cretaceous marine sediments (Álvarez, 1979; Kerr et al., 1996; Toussaint and Restrepo, 1996; Villagómez et al., 2011). The Central Cordillera comprises a poly-metamorphic basement of probably Devonian and Permo-Triassic ages (Ordóñez-Carmona and Pimentel, 2002; Spikings et al., 2014; Toussaint and Restrepo, 1996; Villagómez and Spikings, 2013; Villagómez et al., 2011; Vinasco et al., 2006).

The Eastern Cordillera comprises an early Paleozoic basement covered by Paleozoic sediments and metasedimentary strata, as well as Mesozoic marine sediments deposited in extensional basins, which were inverted in the late Miocene (Mora et al., 2009; Taboada et al., 2000). Precambrian rocks are common both at the eastern flank of the Central Cordillera or as part of isolated massifs in the Eastern Andes.

All these tectono-stratigraphic domains are intruded and covered by Paleozoic to Cenozoic plutonic and volcanic rocks. The spatial and temporal distribution of this magmatic activity has been related to major changes on plate convergence configuration and/or the episodes of terrane accretion (Aspden et al., 1987; Restrepo and Toussaint, 1991).

Jurassic magmatism is more extensively distributed in the Eastern and Central Cordillera of the Colombian Andes as well as in the Upper Magdalena Valley. Based on its spatial distribution it can be separated in three geographic provinces (FIGURE 1):

(1) Isolated and fault bounded massifs that include the Sierra Nevada de Santa Marta, Perijá Range and Guajira Peninsula (Cardona et al., 2006; MacDonald, 1964; Tschanz et al., 1974).
(2) An Eastern Andes province that includes Early Jurassic magmatism in the Santander and San Lucas Massif and the northern termination of the Central Cordillera (Goldsmith et al., 1971; Mantilla et al., 2013; Van der Lelij et al., 2015).

(3) A continuous southern Jurassic belt exposed in the Central Cordillera, Upper Magdalena basin and Garzón Massif that extends to the south to the Putumayo region (Bayona, 1994; Bustamante et al., 2010; Chiaradia et al., 2009; Sillitoe et al., 1982; Villagómez et al., 2011).

Regional paleogeographic models, stratigraphic considerations or scarce geochemical data have been commonly used to propose two different tectonic environments: (1) a continental volcanic arc related with the Pacific subduction (Boschman, et al., 2014; Bustamante et al., 2010; McCourt et al., 1984; Meschede and Frisch, 1998; Pindell and Tabbutt, 1995; Pindell and Erikson, 1993; Spikings et al., 2014; Toussaint, 1995), (2) an intracontinental extensional rifting that can be associated to the breakup of Pangea in the Triassic and Early Jurassic (Cediel et al., 2003; Cochrane et al., 2014; Pindell and Dewey, 1982; Ross and Scotese, 1988).

As already mentioned, the limited precise chronological and compositional database of the Jurassic magmatic rocks has precluded a precise analysis of this magmatism in southern Colombia.

\section{REGIONAL GEOLOGY OF SOUTHERN COLOMBIA AND STRATIGRAPHIC CHARACTERISTICS OF THE JURASSIC MAGMATIC UNITS}

The Andean Cordillera in southern Colombia merges as a single chain to form the Colombian Massif before splitting in the Central and the Eastern Cordillera. The older rocks in this massif include the gneissic basement of the Cocha - Río Tellez Complex and associated meta-sedimentary rocks considered Precambrian and Paleozoic in age (Murcia and Cepeda, 1983; Ponce, 1979). This basement is covered and intruded by Jurassic volcano-sedimentary and plutonic rocks of the Saldaña Formation and the Mocoa batholiths. The basement is unconformably overlain by Early and Late Cretaceous marine strata represented by the Caballlos, Villeta and Rumiyaco Formations (Amaya y Centenaro, 1997), followed by the continental Pepinos Formation and a widespread Neogene volcanic cover (Mora et al., 1998; Murcia and Pichler, 1987). 


\section{Saldaña Formation}

Regional studies have correlated volcanic and pyroclastic rocks exposed in southern Colombia along the Putumayo, Caquetá and Mocoa rivers, with the Saldaña Formation of the Upper Magdalena Valley and the Huila area (Ayala et al., 2012; Bayona, 1994; Marquínez and Velandia, 2001).

In southern Colombia this volcano-sedimentary formation is exposed in the high topographic altitudes of the Caqueta, Putumayo and Mocoa rivers. It is exposed along three SW-NE belts (FIGURE 2). It includes volcanic and porphyritic rocks ranging from basaltic to rhyolitic composition, crystalline and vitreous andesitic to rhyolitic tuffs, agglomerates and ignimbrites. Several tuffaceous sandstones composed by quartz and feldspar crystals and volcanic rock fragments are intercalated with the volcanic rocks.

The Saldaña Formation presents faulted and depositional contacts with Cretaceous marine sediments and intrusive relations with the Mocoa Batholith (FIGURE 2B). Published age constraints from the Saldaña Formation came from paleontological results in the Upper Magdalena Valley, which is located to the north of the study area. They include Late Triassic to Early Jurassic depositional ages (Widemann and Mojica, 1980). No previous absolute geochronological data have been reported for the volcanic rocks of the Saldaña Formation in the Putumayo region.

A
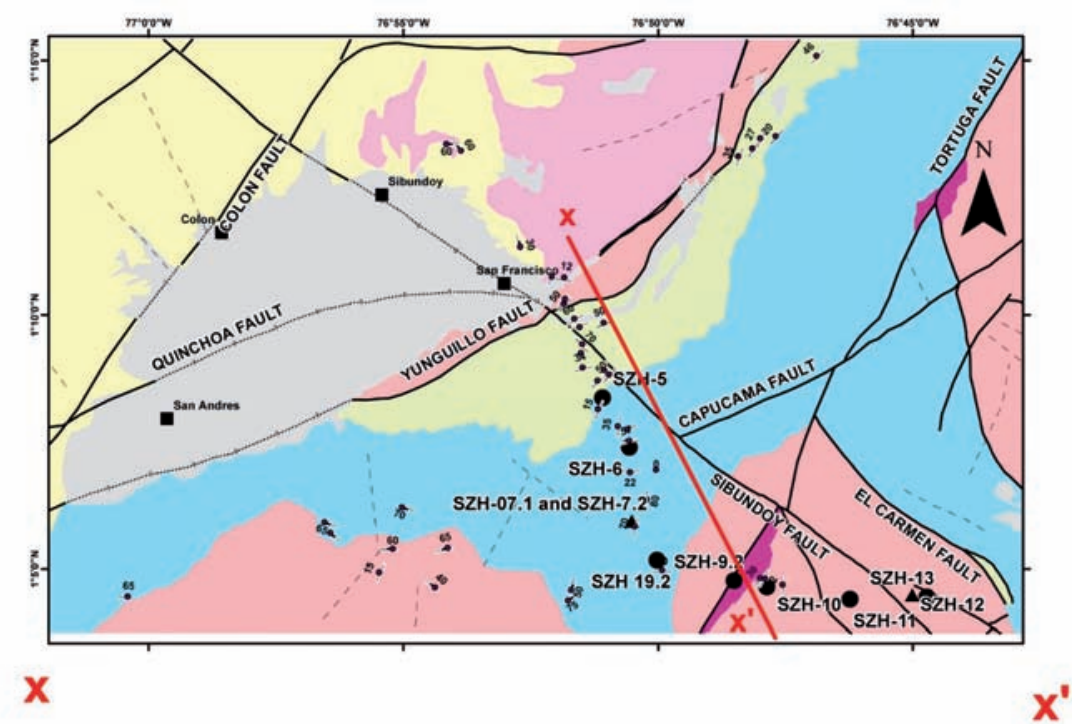

B
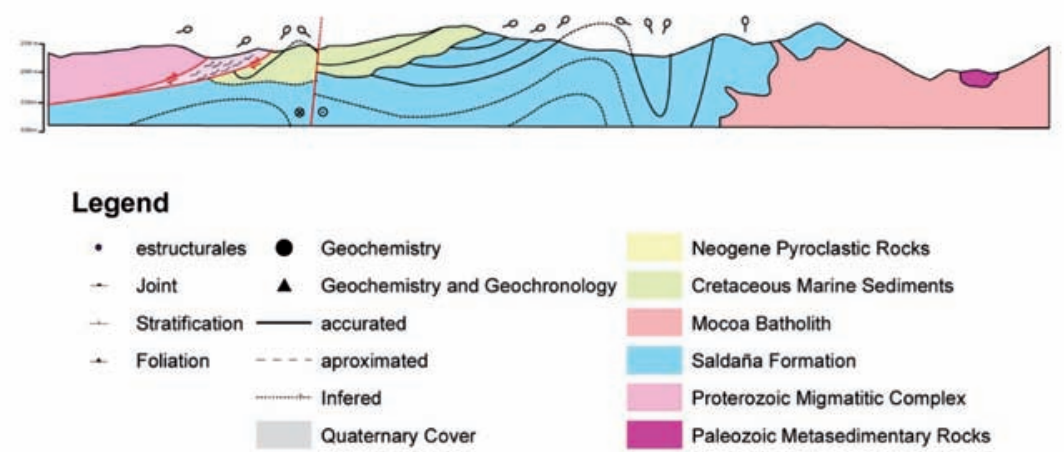

FIGURE 2. A. Geologic map of the studied area including samples location. Modified from Núñez (2003). B. Geological cross section from the studied area.

\section{Mocoa Batholith}

The Mocoa Batholith extends from the Ecuadorian border towards northern Putumayo in Colombia. This unit is exposed as a series of segmented SW-NW elongated bodies. It is composed of monzogranites with minor syenogranites, granodiorites and quartzmonzonites. Porphyritic facies with similar compositions are exposed at the borders of the body. 
Whole rock and biotite K-Ar ages in the Mocoa Batholith yielded ages between $170 \mathrm{Ma}$ and $210 \mathrm{Ma}$, whereas feldspar and sericite ages between $136 \mathrm{Ma}$ and 166 Ma (Jaramillo et al., 1980; Sillitoe et al., 1982). Although calculated ages may reflect cooling, mineralization events or argon loss, the K-Ar method not assess accurately the age of this unit (McDougall and Harrison, 1999).

\section{METHODS}

\section{Whole rock geochemistry}

Bulk whole rock chemical composition of 10 samples was determined by inductively coupled plasmamass spectrometry (ICP-MS) at Acme Analytical Laboratories Ltd. in Vancouver, Canada. A 0.2 g aliquot is weighed into a graphite crucible and mixed with $1.5 \mathrm{~g}$ of $\mathrm{LiBO} 2$ flux. The crucibles are placed in and heated to $1050^{\circ} \mathrm{C}$ for 15 minutes. The molten sample is dissolved in $5 \% \mathrm{HNO}_{3}$. Calibration standards and reagent blanks are added to the sample sequence. Sample solutions are aspirated into an ICP emission spectrograph (Jarrel Ash Atom Comb 975) for determining major oxides and certain trace elements (Ba, Nb, Ni, Sr, Sc, Y and Zr), while the sample solutions are aspirated into an ICP-MS (Perkin-Elmer Elan 6000) for determination of the trace elements, including rare earth elements.

\section{U-Pb LA-ICPMS}

Heavy mineral concentrates of the $<350 \mu$ fraction were crushed, sieved and hydraulically separated. Subsequent magnetic and heavy liquid separation with methylene iodide was used to concentrate zircons. Inclusion-free zircons from the non-magnetic fraction were then handpicked under a binocular microscope. Thirty four and twenty one zircons of the samples SZH 12.1 and SZH 7.2, respectively, were mounted in epoxy and polished to half thickness for laser ablation analysis using laser ablation-inductively coupled plasma-mass spectrometry. All LA-ICP-MS U-Pb analyses were conducted at Washington State University using a New Wave Nd:YAG UV 213-nm laser coupled to a Thermo Finnigan Element 2 single collector, double-focusing, magnetic sector ICPMS. He and Ar carrier gases delivered the sample aerosol to the plasma. Operating procedures and parameters are discussed in greater depth by (Chang et al., 2006) and are only briefly outlined here. Each analysis takes approximately 35 seconds, it consisted of a short blank analysis followed by 300 sweeps through masses 204, $206,207,208,232,235$, and 238 , with a repetition rate of $10 \mathrm{~Hz}$, and a spot size of $30 \mu \mathrm{m}$.
LA-ICP-MS isotopic analyses are affected by two forms of inter-element fractionation that must be corrected (Kosler and Sylvester, 2003). Timedependent fractionation results from the more efficient volatilization of $\mathrm{Pb}$ over $\mathrm{U}$ as the laser excavates successively deeper levels in the ablation pit during an analysis, which in turn leads to an increase in $206 \mathrm{~Pb} / 238 \mathrm{U}$ and $207 \mathrm{~Pb} / 235 \mathrm{U}$ ratios with time (Eggins et al., 1998). It has been demonstrated that $\mathrm{U} / \mathrm{Pb}$ fractionation is approximately linear over the short time of the analysis (Kosler and Sylvester, 2003). By definition, time-dependent fractionation is zero at the beginning of the analysis. Regression of time series data to the intercept at $t=0$, therefore, yields the point at which time- dependent fractionation equals zero. We used two zircon standards: Peixe, with an age of $564 \mathrm{Ma}$ (Dickinson and Gehrels, 2003), and FC-1, with an age of $1099 \mathrm{Ma}$ (Paces and Miller, 1993). Peixe was used to correct the $238 \mathrm{U} / 206 \mathrm{~Pb}$ and 235U/207Pb ratios and FC-1 was used to correct the $207 \mathrm{~Pb} / 206 \mathrm{~Pb}$ ratios.

Time-independent (or static) fractionation is the largest source of uncertainty in LA-ICP-MS U-Pb geochronology and results from mass and elemental static fractionation in the plasma and also poorly understood laser-matrix effects (Kosler and Sylvester, 2003). It is corrected by normalizing $\mathrm{U} / \mathrm{Pb}$ and $\mathrm{Pb} / \mathrm{Pb}$ ratios of the unknowns to the zircon standards (Chang et al., 2006; Shuster and Farley, 2009).

Common $\mathrm{Pb}$ can represent a proportionally large contribution to the total $\mathrm{Pb}$ in Mesozoic and younger U-poor zircons. However, common $\mathrm{Pb}$ is typically not significant in LA-ICP-MS analyses, most likely because it is concentrated in cracks and inclusions, which can be avoided. When this is not possible, the influence of common $\mathrm{Pb}$ is easy to recognize on TeraWasserburg diagrams because analyses tend to line up on a steep linear trajectory that can be anchored at a reasonable $207 \mathrm{~Pb} / 206 \mathrm{~Pb}$ common lead composition (y-intercept) (DeGraaff-Surpless et al., 2002). Common $\mathrm{Pb}$ corrections were made on these analyses using the 207Pb methods (Williams, 1998). Uranium-lead data were reduced using Isoplot (Ludwig, 2007). The ages that we report are followed by two uncertainties: the first is derived from the concordant or intercept age calculation alone, and the second represents our systematic uncertainty during that session, with the error from the standards quadratically added to the analytical error. 


\section{RESULTS}

\section{Petrography}

The SW-NE cross section (FIGURE 2) includes an intercalation of gneisses and biotite schist from the Paleozoic La Cocha - Río Tellez complex. These gneisses are overthrust by Jurassic mylonitized hornblende-biotite quartzfeldspathic rocks oriented $\mathrm{N}-\mathrm{S}$ and dipping $50^{\circ}$ to the east. These mylonitized granitoids may have Jurassic plutonic protoliths. Thin sections present an irregular foliation defined by chlorite formation after amphibole separated by undulatory quartz and mantle and core structures of the plagioclase. These observations indicate at least greenschist facies deformation.

This mylonitized plutonic remnant is also overthrusting Cretaceous sedimentary rocks of the Caballos Formation. The Cretaceous rocks include an intercalation of folded lutites and well sorted quartz sandstones that unconformably overlies the Saldaña Formation to the east (FIGURE 2). The Saldaña Formation is made of an intercalation of volcanic lavas and tuffs dipping between $40-90^{\circ}$ to the northwest and the southeast.

Within the easternmost segment of the profile, the Mocoa Batholith and associated dikes that intrude the Saldaña Formation are exposed (FIGURE 2B). The Mocoa Batholith includes diorites, granodiorites, granites and porphyritic dikes. Samples contain hornblende (20-50\%), plagioclase (30-60\%), K-feldspar (15$30 \%)$ with variable quartz $(5-40 \%)$ and minor zircon, apatite, biotite and muscovite. The porphyritic facies include a micro-crystalline matrix ( $>60 \%)$ composed by quartz and plagioclase with amphibole, plagioclase and feldspar crystals. Both quartz and K-feldspar are present as a late crystallization phase, as suggested by the more anhedral and intercrystal distribution. An overimposed alteration is indicated by the presence of sericite, opaques and carbonates replacing the preexisting minerals (FIGURE 3A).

Petrographic analysis from the Saldaña Formation indicates the presence of fine-grain basalts composed of clinopyroxene, plagioclase and opaque minerals with minor olivine, ortopyroxene and epidote (FIGURE 3B). Intermediate andesitic volcanic rocks include amphibole, quartz and plagioclase as well as a lack of olivine. Clinopyroxene crystals are more ehuedral and seems to be early cristallyzation phase, a feature that may be a consequence of the presence of water that commonly suppressed the early crystallization of plagioclase in wet arc magmas (Sisson and Grove, 1993).
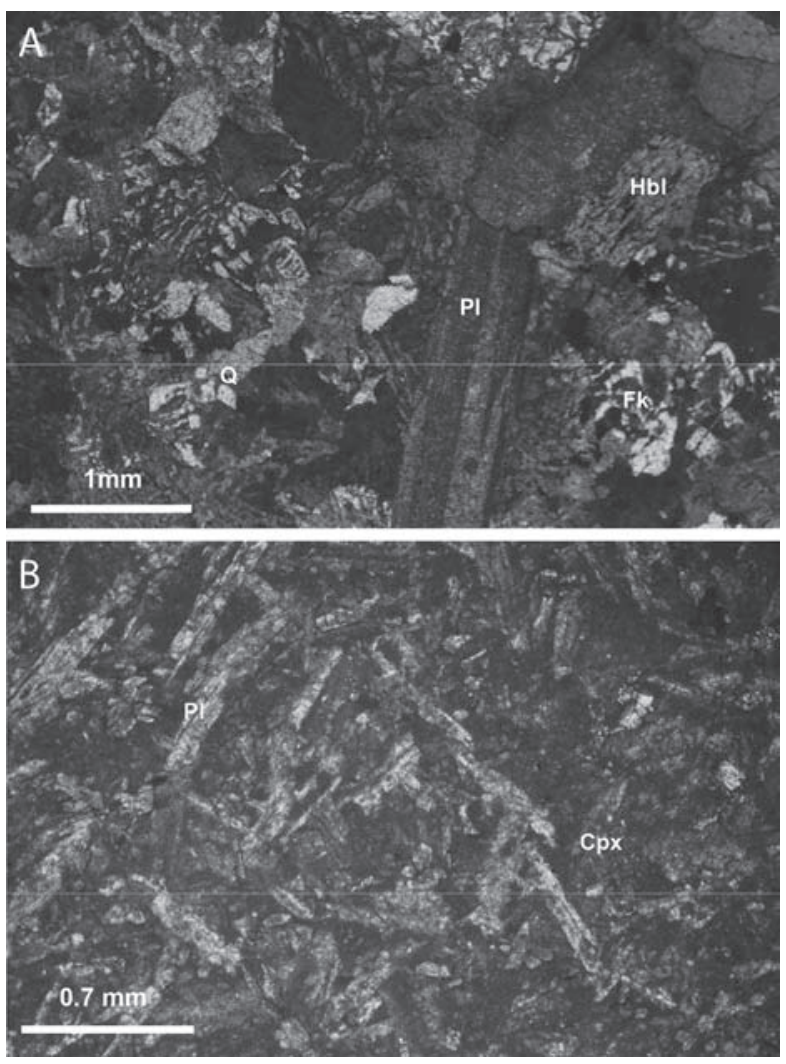

FIGURE 3. A. Polarized light images from a Mocoa Batholith granite, exsolution textures in K-feldspars; B. Polarized light image from Saldaña Formation. Cpx = Clinopyroxene, $\mathrm{Pl}=$ Plagioclase, $\mathrm{Q}=$ Quartz and Fk = K-feldspar.

\section{Whole rock geochemistry}

Ten samples were selected for major and trace element geochemistry, five from the Saldaña Formation and five from the Mocoa Batholith Results are presented in supplementary TABLE 1 . When compared in bi-variate diagrams, including $\mathrm{SiO}_{2}$ vs $\mathrm{CaO}, \mathrm{K}_{2} \mathrm{O}$ and $\mathrm{Fe}_{2} \mathrm{O}_{3}$ follow a correlation trend, suggesting that the samples can be related to a similar magmatic evolution. The apparent lack of correlation in an intermediate samples and some dispersion in the basaltic samples may be related to hydrothermal alteration that have remobilized some of the major elements, as is also seen in high lost on ignition values (TABLE 1).

Within multi-elemental plots all samples show similar patterns of enrichment including high $\mathrm{Pb}$ values (FIGURE 4). All samples are grouped within the high$\mathrm{K}$ series using the classification scheme of (Peccerillo and Taylor, 1976) (FIGURE 5A). Mg\# values range between 34 and 58 that can be related to different degrees of crystal fractionation (FIGURE 5B). 
TABLE 1. Geochemical data.

\begin{tabular}{|c|c|c|c|c|c|c|c|c|c|c|}
\hline & SZH-6 & SZH-19.2 & SZH-5 & SZH-7.1 & SZH-7.2 & SZH-10 & SZH-9.2 & SZH-11.1 & SZH-12.1 & SZH-13 \\
\hline Wgt (\%) & andesite & basalt & basalt & basalt & andesite & diorite & granite & granite & granite & granite \\
\hline $\mathrm{SiO}_{2}$ & 51.79 & 48.19 & 45.62 & 47.52 & 62.89 & 59.31 & 65.98 & 73.72 & 69.07 & 63.53 \\
\hline $\mathrm{Al}_{2} \mathrm{O}_{3}^{2}$ & 17.23 & 17.03 & 18.95 & 16.55 & 17.24 & 17.96 & 15.68 & 13.78 & 15.15 & 16.98 \\
\hline $\mathrm{Fe}_{2}^{2} \mathrm{O}_{3}^{3}$ & 6.66 & 10.88 & 10 & 10.23 & 4.7 & 6.39 & 3.68 & 1.42 & 2.7 & 4.45 \\
\hline $\mathrm{MgO}^{2}$ & 1.77 & 7.91 & 5.04 & 7.1 & 1.45 & 2.06 & 1.08 & 0.24 & 0.8 & 1.36 \\
\hline $\mathrm{CaO}$ & 5.53 & 3.74 & 8.92 & 7.36 & 2.69 & 3.23 & 3.04 & 0.55 & 1.89 & 2.98 \\
\hline $\mathrm{Na}_{2} \mathrm{O}$ & 0.7 & 2.43 & 1.9 & 2.93 & 4.05 & 4.09 & 3.98 & 3.8 & 3.78 & 4.59 \\
\hline $\mathbf{K}_{2} \mathbf{O}$ & 7.96 & 0.88 & 0.84 & 1.43 & 3.67 & 3.01 & 3.63 & 4.64 & 4.29 & 3.27 \\
\hline $\mathrm{TiO}_{2}$ & 0.57 & 1.28 & 1.07 & 1.23 & 0.48 & 0.63 & 0.38 & 0.18 & 0.32 & 0.49 \\
\hline $\mathrm{P}_{2} \mathrm{O}_{5}$ & 0.2 & 0.63 & 0.38 & 0.61 & 0.15 & 0.31 & 0.14 & 0.03 & 0.12 & 0.23 \\
\hline MnO & 0.14 & 0.19 & 0.19 & 0.17 & 0.12 & 0.27 & 0.2 & 0.05 & 0.19 & 0.12 \\
\hline $\begin{array}{l}\mathrm{Cr}_{2} \mathrm{O}_{3} \\
\mathrm{ppm}\end{array}$ & 0.006 & 0.032 & 0.007 & 0.039 & 0.018 & 0.008 & 0.015 & 0.012 & 0.013 & 0.009 \\
\hline $\mathbf{N i}$ & 206 & 218 & 98 & 186 & 539 & 317 & 539 & 406 & 510 & 355 \\
\hline Sc & 12 & 24 & 25 & 23 & 9 & 9 & 6 & 2 & 4 & 8 \\
\hline LOI & 7.2 & 6.5 & 6.8 & 4.4 & 2.1 & 2.5 & 1.9 & 1.4 & 1.4 & 1.7 \\
\hline Sum & 99.76 & 99.67 & 99.7 & 99.63 & 99.66 & 99.75 & 99.78 & 99.89 & 99.76 & 99.76 \\
\hline $\mathrm{Ba}$ & 1337 & 575 & 637 & 833 & 1692 & 1028 & 1168 & 819 & 1167 & 1007 \\
\hline $\mathrm{Be}$ & $<1$ & $<1$ & $<1$ & $<1$ & $<1$ & 2 & 1 & 2 & 1 & 2 \\
\hline Co & 11.3 & 39.6 & 28.8 & 33.8 & 9.9 & 9.5 & 5.2 & 1.3 & 5.2 & 5.8 \\
\hline Cs & 4.6 & 0.1 & 3.2 & 0.8 & 1.5 & 0.6 & 0.5 & 0.6 & 0.7 & 0.6 \\
\hline Ga & 15.8 & 16.6 & 20.3 & 17.6 & 17.1 & 19.6 & 16.1 & 13.1 & 14.8 & 18.2 \\
\hline Hf & 3.6 & 3.8 & 2.8 & 3.8 & 5.1 & 3.4 & 4.3 & 4.4 & 4 & 6.2 \\
\hline $\mathbf{N b}$ & 4.8 & 10.7 & 5 & 12 & 6.4 & 7.3 & 6.2 & 12.8 & 9.9 & 8.7 \\
\hline $\mathbf{R b}$ & 256.1 & 13 & 15.8 & 26.4 & 69.8 & 74.6 & 82.9 & 109.8 & 102.6 & 73 \\
\hline Sn & $<1$ & 1 & $<1$ & 1 & 2 & 1 & 2 & $<1$ & 1 & 1 \\
\hline $\mathrm{Sr}$ & 139.5 & 460.1 & 637.9 & 754.6 & 732.7 & 584.9 & 425.4 & 129.7 & 425 & 581.2 \\
\hline Ta & 0.3 & 0.5 & 0.2 & 0.5 & 0.4 & 0.4 & 0.4 & 1.2 & 0.7 & 0.5 \\
\hline Th & 4.8 & 1.5 & 1.7 & 1.6 & 6.7 & 4.4 & 7.8 & 10.2 & 11.5 & 6.6 \\
\hline $\mathbf{U}$ & 1.5 & 0.6 & 0.5 & 0.5 & 1.8 & 1.5 & 2.2 & 2.8 & 2.5 & 1.7 \\
\hline $\mathbf{V}$ & 113 & 184 & 251 & 190 & 73 & 99 & 45 & $<8$ & 36 & 60 \\
\hline W & 3.6 & $<0,5$ & $<0,5$ & $<0,5$ & 0.6 & 0.5 & 0.7 & 0.5 & 0.6 & $<0,5$ \\
\hline $\mathbf{Z r}$ & 112.4 & 150.1 & 104.7 & 162.2 & 167.2 & 115.1 & 146.1 & 132.9 & 133.3 & 231.9 \\
\hline$Y$ & 17.9 & 25.8 & 22.1 & 26.7 & 18.2 & 25.6 & 15.8 & 13.2 & 17.4 & 24.5 \\
\hline La & 22.8 & 26.7 & 21.2 & 31.6 & 25.2 & 29.2 & 26 & 30.5 & 36.9 & 35.8 \\
\hline $\mathrm{Ce}$ & 43.3 & 60.7 & 47 & 69.1 & 48.3 & 57.1 & 48.6 & 53.4 & 68.3 & 73.4 \\
\hline Pr & 5.1 & 7.71 & 6.12 & 8.91 & 5.6 & 7.12 & 5.33 & 5.75 & 7.01 & 8.72 \\
\hline Nd & 20.9 & 33.8 & 25.9 & 37.3 & 22.2 & 28.5 & 19.6 & 18.6 & 24.3 & 34.3 \\
\hline Sm & 3.89 & 6.13 & 5.08 & 6.78 & 3.74 & 5.34 & 3.12 & 2.78 & 3.83 & 5.53 \\
\hline $\mathbf{E u}$ & 1.12 & 1.83 & 1.57 & 2.02 & 1.06 & 1.4 & 0.83 & 0.55 & 0.9 & 1.2 \\
\hline Gd & 3.55 & 5.7 & 4.83 & 6.17 & 3.4 & 4.86 & 2.85 & 2.06 & 3.24 & 4.53 \\
\hline $\mathbf{T b}$ & 0.55 & 0.84 & 0.73 & 0.89 & 0.53 & 0.76 & 0.44 & 0.34 & 0.51 & 0.74 \\
\hline Dy & 3.17 & 4.58 & 4.11 & 4.94 & 3.19 & 4.16 & 2.62 & 1.99 & 2.83 & 4.02 \\
\hline Ho & 0.64 & 0.93 & 0.77 & 0.93 & 0.64 & 0.85 & 0.55 & 0.43 & 0.61 & 0.83 \\
\hline $\mathbf{E r}$ & 1.78 & 2.6 & 2.33 & 2.63 & 1.89 & 2.48 & 1.63 & 1.45 & 1.86 & 2.54 \\
\hline Tm & 0.28 & 0.38 & 0.33 & 0.39 & 0.31 & 0.39 & 0.27 & 0.24 & 0.3 & 0.39 \\
\hline $\mathbf{Y b}$ & 1.84 & 2.42 & 2 & 2.38 & 1.93 & 2.49 & 1.8 & 1.75 & 1.97 & 2.66 \\
\hline Lu & 0.3 & 0.37 & 0.33 & 0.37 & 0.31 & 0.39 & 0.31 & 0.29 & 0.32 & 0.4 \\
\hline Ctot & 1.17 & 0.05 & 0.13 & 0.06 & 0.2 & 0.03 & 0.05 & 0.04 & 0.03 & 0.03 \\
\hline Stot & $<0,02$ & $<0,02$ & $<0,02$ & $<0,02$ & 0.02 & $<0,02$ & $<0,02$ & $<0,02$ & $<0,02$ & $<0,02$ \\
\hline Mo & 0.5 & 0.1 & 0.2 & 0.4 & 1.9 & 0.4 & 1.2 & 0.6 & 0.5 & 0.3 \\
\hline $\mathrm{Cu}$ & 7.9 & 53.4 & 70 & 54 & 29 & 7.8 & 47.4 & 16.2 & 20.7 & 6.5 \\
\hline $\mathbf{P b}$ & 7 & 12.7 & 2.1 & 6.1 & 22.6 & 3.9 & 23.7 & 5 & 52.7 & 3.8 \\
\hline $\mathrm{Zn}$ & 47 & 115 & 40 & 65 & 69 & 94 & 81 & 23 & 207 & 51 \\
\hline $\mathrm{Ni}$ & 191.2 & 202.6 & 77.5 & 182.7 & 533.1 & 272.1 & 508 & 412.5 & 525.2 & 324.9 \\
\hline As & 18.5 & 2 & 7.6 & 8.7 & 109.9 & 7.7 & 21.7 & 38.7 & 6.9 & 4.6 \\
\hline Cd & $<0,1$ & 0.2 & 0.1 & $<0,1$ & 0.6 & $<0,1$ & 0.3 & $<0,1$ & 1.2 & $<0,1$ \\
\hline Sb & 1 & $<0,1$ & $<0,1$ & $<0,1$ & 0.2 & $<0,1$ & 0.1 & $<0,1$ & $<0,1$ & $<0,1$ \\
\hline $\mathbf{B i}$ & $<0,1$ & $<0,1$ & $<0,1$ & $<0,1$ & $<0,1$ & $<0,1$ & $<0,1$ & $<0,1$ & 0.2 & $<0,1$ \\
\hline Ag & $<0,1$ & 0.1 & $<0,1$ & $<0,1$ & 0.2 & $<0,1$ & $<0,1$ & $<0,1$ & $<0,1$ & $<0,1$ \\
\hline Au & 0.6 & 1.5 & 6.4 & 0.8 & 139.8 & $<0,5$ & 1.5 & 3.1 & 6.4 & 2.9 \\
\hline Hg & 0.01 & $<0,01$ & $<0,01$ & $<0,01$ & 0.02 & $<0,01$ & $<0,01$ & $<0,01$ & $<0,01$ & $<0,01$ \\
\hline TI & $<0,1$ & $<0,1$ & $<0,1$ & $<0,1$ & $<0,1$ & $<0,1$ & $<0,1$ & $<0,1$ & $<0,1$ & $<0,1$ \\
\hline $\mathrm{Se}$ & $<0,5$ & $<0,5$ & $<0,5$ & $<0,5$ & $<0,5$ & $<0,5$ & $<0,5$ & $<0,5$ & $<0,5$ & $<0,5$ \\
\hline
\end{tabular}



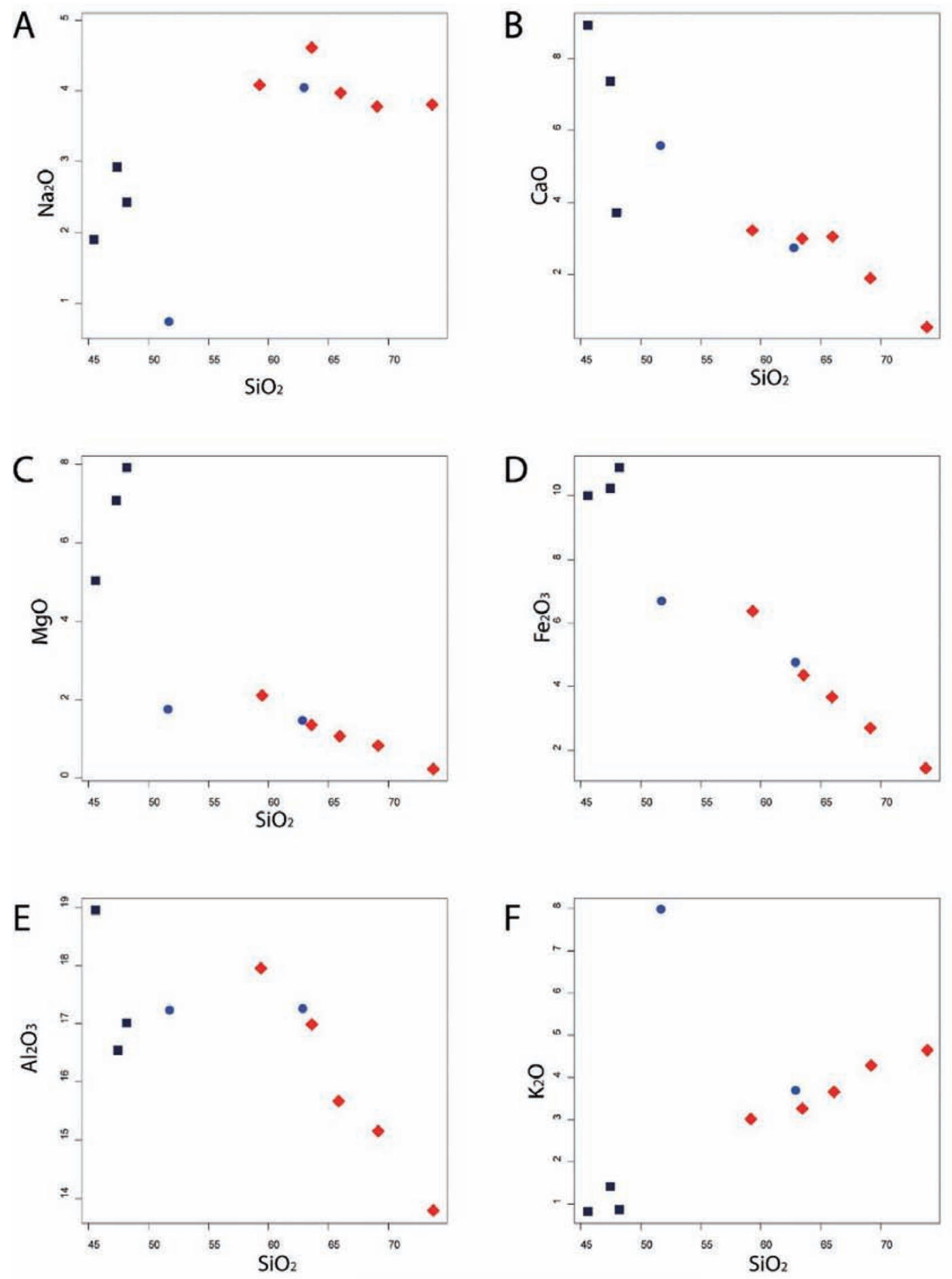

\section{- Mocoa Batholith \\ - Saldaña Fm. (Basalts) \\ Saldaña Fm. (intermediate)}

FIGURE 4. Harker diagrams. A. $\mathrm{SiO}_{2}$ vs $\mathrm{Na}_{2} \mathrm{O}$; B. $\mathrm{SiO}_{2}$ vs $\mathrm{CaO} ;$ C. $\mathrm{SiO}_{2}$ vs $\mathrm{MgO} ; \mathbf{D} . \mathrm{SiO}_{2}$ vs $\mathrm{FeO}_{3} ; \mathbf{E}_{2} \mathrm{SiO}_{2}$ vs $\mathrm{Al}_{2} \mathrm{O}_{3}$; F. $\mathrm{SiO}_{2}$ vs $\mathrm{K}_{2} \mathrm{O}$. 

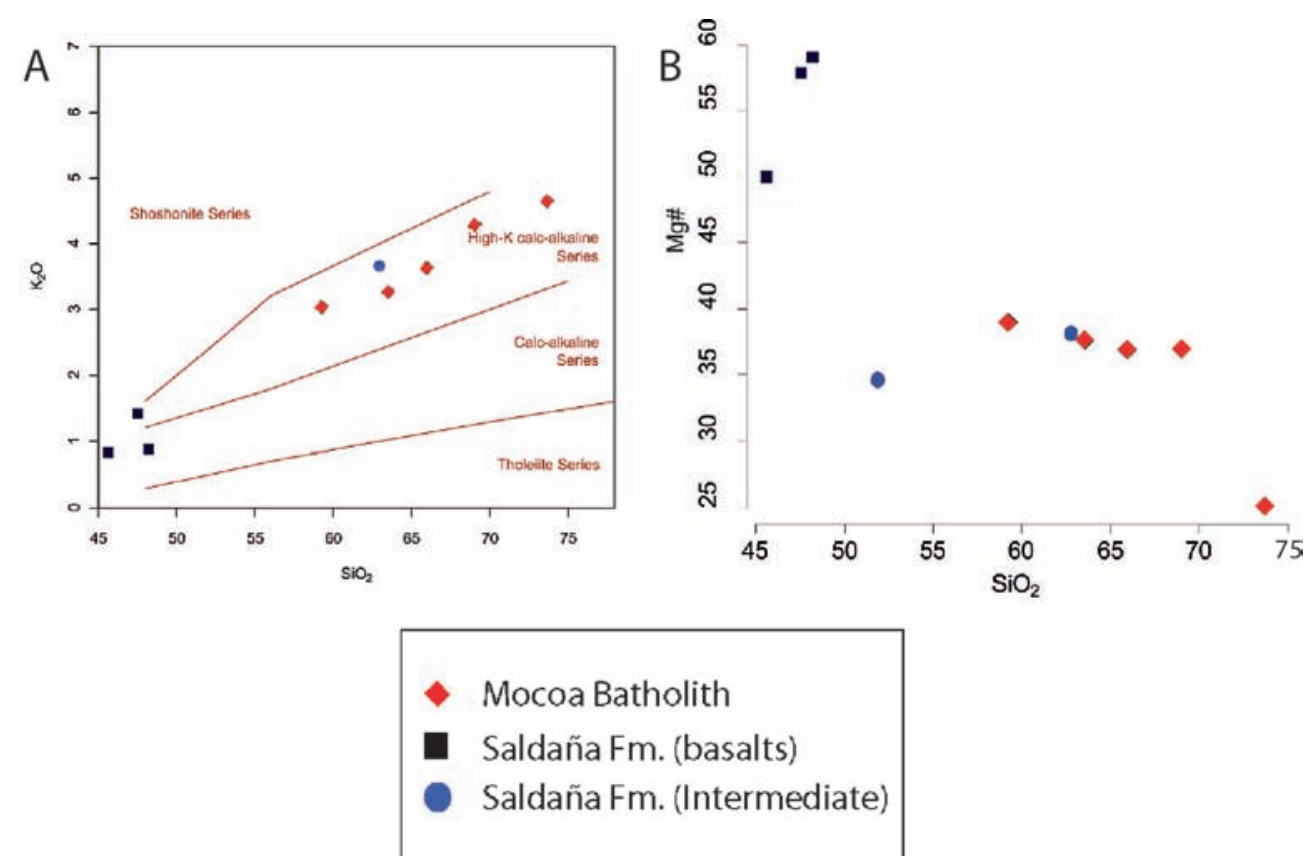

FIGURE 5. A. $\mathrm{SiO}_{2}$ vs $\mathrm{K}_{2} \mathrm{O}$ of Peccerillo and Taylor (1976); B. $\mathrm{SiO}_{2}$ vs $\mathrm{Mg \#}$

\section{Saldaña Formation}

Samples from the Saldaña Formation are characterized by $\mathrm{SiO}_{2}$ values between $45.6 \%-62.8 \%$, with $\mathrm{Na}_{2} \mathrm{O}$ varying between $0.7 \%$ and $4.05 \%$ and $\mathrm{K}_{2} \mathrm{O}$ values between $0.84 \%$ 7.96\%. MgO values lay between $1.95 \%-7.41 \%$, whereas $\mathrm{Fe}_{2} \mathrm{O}_{3}$ also shows a considerable variation between 4.7-10.88. $\mathrm{Al}_{2} \mathrm{O}_{3}$ is less variable with values between $16.55 \%-18.95 \%$. When compared against $\mathrm{MgO}, \mathrm{Ni}$ and $\mathrm{TiO}_{2}$ (not shown, TABLE 2) also follow a differentiation trend which is characteristic of crystal fractionation due to the accumulation of pyroxene and titanite.

Within the TAS diagram after (Bas et al., 1986) the volcanic rocks vary from basalts to trachy-dacites (FIGURE 6A). Harker bivariate plots from the Saldaña Formation are characterized by a positive correlation of $\mathrm{SiO}_{2}$ against $\mathrm{Na}_{2} \mathrm{O}$ and $\mathrm{K}_{2} \mathrm{O}$ and negative correlation with $\mathrm{CaO}, \mathrm{MgO}$ and $\mathrm{Fe}_{2} \mathrm{O}_{3}$ (FIGURE 4) that may be related to crystal fractionation of olivine, clinopyroxene and Ca-rich plagioclase.

Rare earth elements patterns (REE) normalized to chondrite (Nakamura, 1974) (FIGURE 7B) are characterized by enrichment in light rare earth elements (LREE) when compared with heavy rare earth elements (HREE). The samples show a negative Eu/Eu* anomaly between 0.95 and 0.97 and $\mathrm{La} / \mathrm{YbN}$ between 7.07 and 8.97. Multi-elemental patterns normalized to the primitive mantle of (Sun and McDonough, 1989) (FIGURE 7A) yielded a relative enrichment of large ion lithophile elements (LILE) such as $\mathrm{Ba}, \mathrm{Rb}, \mathrm{Sr}$ and $\mathrm{Th}$ and well-defined negative $\mathrm{Nb}, \mathrm{P}$, and Ti anomalies, the high normalized HREE reveals no residual garnet in the melt and therefore is more akin to shallower melting conditions.

Tectonic discrimination diagrams after (Schandl and Gorton, 2002) for intermediate rocks and (Wood, 1980) for basaltic rocks that considered Th enrichment due to the non-conservative behavior of Th in subduction zones, and the relation of Ta with the presence of $\mathrm{Ti}$ minerals in the source, both show a continental arc affinity (FIGURE 6C and 6B).

\section{Mocoa Batholith}

$\mathrm{SiO}_{2}$ values range between $59.31 \%$ and $73.72 \% ; \mathrm{Na}_{2} \mathrm{O}$ values are between 3.78 and 4.59; $\mathrm{K}_{2} \mathrm{O}$ varies between $3.01 \%$ and $4.64 \%$. Following Cox et al. (1979), samples can be classified as granodiorite to granite (FIGURE 8A).

Trace elements patterns of the Mocoa Batholith show remarkable similarities with the analyzed samples from the Saldaña Formation. REE patterns normalized to chondrite (after Nakamura, 1974) are characterized by relative enrichment of LREE compared to HREE (FIGURE 7A), with $(\mathrm{La} / \mathrm{Yb}) \mathrm{N}$ varying between 7.82 and 12.49. A well-defined negative Europium anomaly is marked by $\mathrm{Eu} / \mathrm{Eu}^{*}$ values between 0.71 and 0.84 . Multielement patterns normalized to the primitive mantle after Sun and McDonough (1989) (FIGURE 7B) show 
a relative enrichment of large ion lithophile elements (LILE) such a as $\mathrm{Ba}, \mathrm{Rb}, \mathrm{Sr}$ and $\mathrm{Th}$ and well defined after Pearce et al. (1984) negative Nb, P, and Ti anomalies.
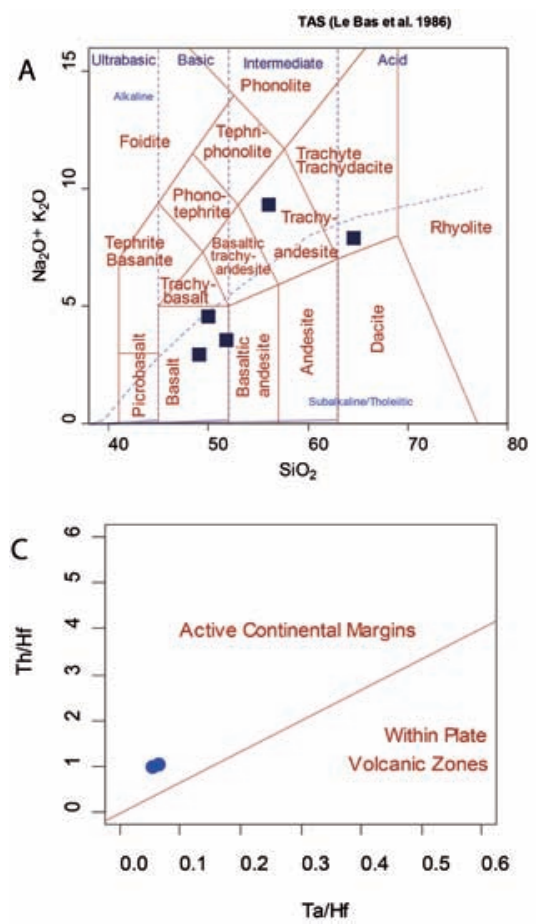

On the tectonic discrimination diagrams (Harris et al., 1986; Pearce et al., 1984) all the samples show a magmatic arc affinity (FIGURE 8 B and 8C).

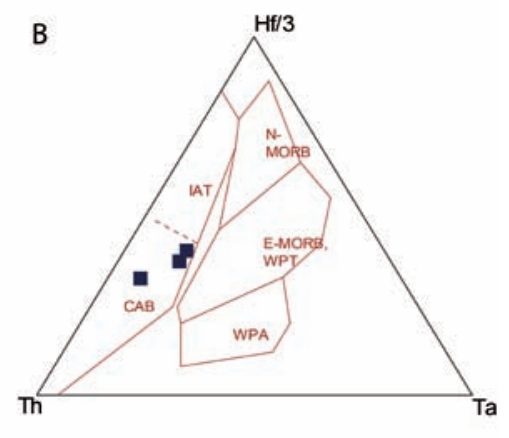

- Saldaña Fm. (Basalts)

Saldaña Fm. (intermediate)

FIGURE 6. Geochemistry of the samples of the Saldaña Formation. A. $\mathrm{SiO}_{2}$ vs $\mathrm{Na}_{2} \mathrm{O}+\mathrm{K}_{2} \mathrm{O}$ TAS diagram (after Bas et al., 1986); B. (Hf/3) - Th - Ta (after Wood, 1980); C. Ta/Hf (after Schandl and Gorton, 2002).
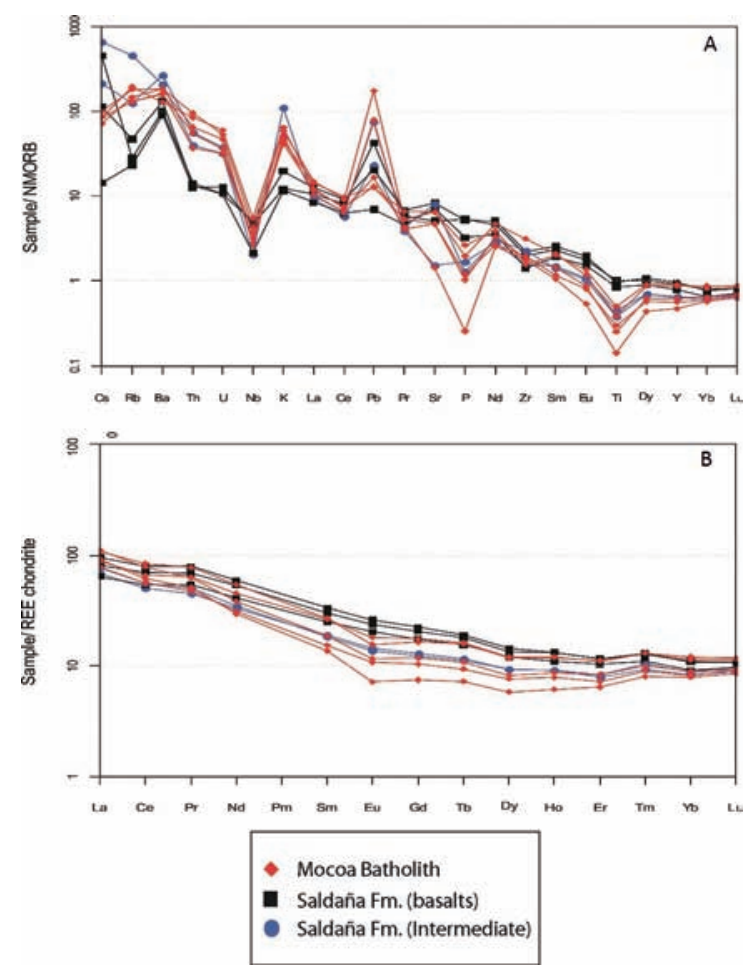

FIGURE 7. A. Multielement patterns normalized to primitive mantle according with Sun and McDonough (1989).

B. REE patterns normalized to chondrite (after Nakamura, 1974). 
TAS (Cox et al. 1979)
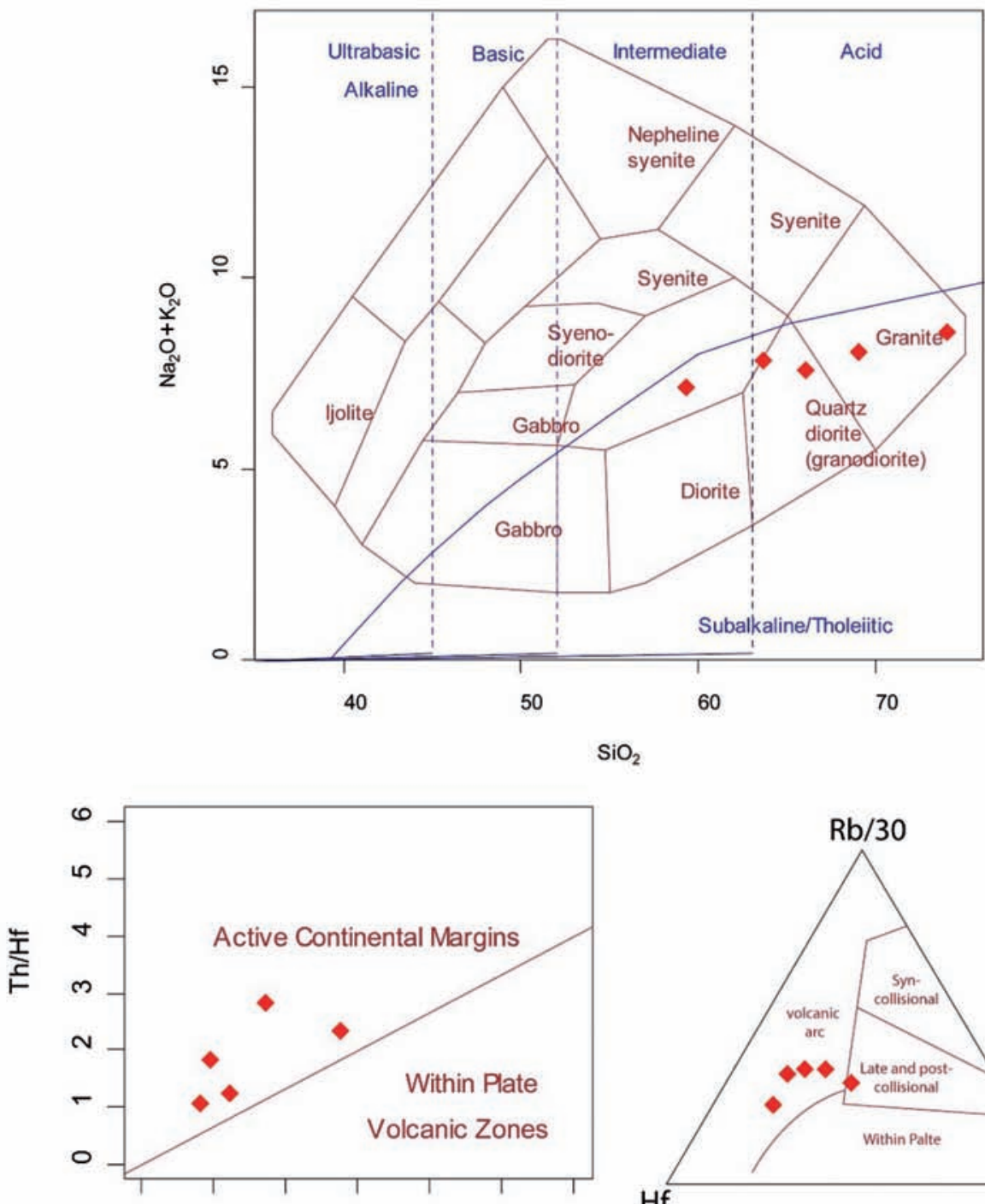

$\begin{array}{lllllll}0.0 & 0.1 & 0.2 & 0.3 & 0.4 & 0.5 & 0.6\end{array}$

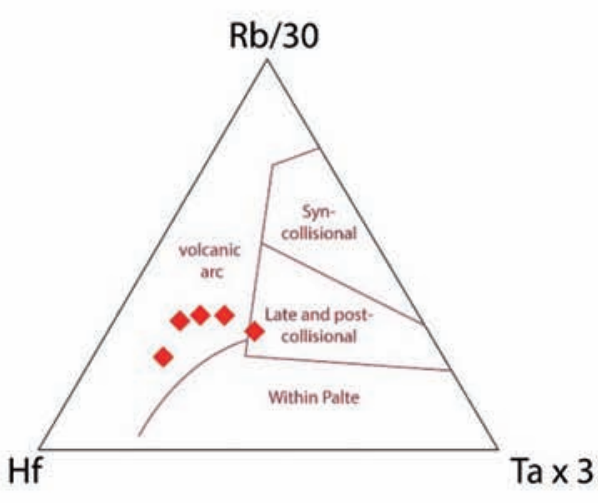

$\mathrm{Ta} / \mathrm{Hf}$

\section{Mocoa Batholith}

FIGURE 8. Geochemistry of the Mocoa samples. A. $\mathrm{SiO}_{2}$ vs $\mathrm{Na}_{2} \mathrm{O}+\mathrm{K}_{2} \mathrm{O}$ (after Cox et al., 1979); B. Geotectonic discrimination of Pearce et al. (1984); C. the Hf - Rb/30 - Ta*3 discrimination diagram for granites (after Harris et al. 1986).

\section{$\mathrm{U}-\mathrm{Pb}$ geochronology}

Two samples from the Saldaña Formation and Mocoa Batholith were selected for U-Pb geochronological analysis. Calculated ages and the Tera-Wasserburg diagrams are presented in Figure 9, geochronological data is reported in Table 2.
34 Zircons from granite of the Mocoa Batholith yielded an age of 180.4 +/- 1.6 Ma (FIGURE 9A) considered as the crystallization age of the plutonic body. Older zircons with ages of 270 Ma 1000 Ma and 1500 Ma may be either related to the source area or partially assimilated crystals. 21 zircons from a porphyritic andesite of the Saldaña Formation have yield an age of $185.9+/-1.4 \mathrm{Ma}$ (FIGURE 9C) that we interpret as a magmatic crystallization age. 
U-Pb LA-ICP-MS geochronology and geochemistry of Jurassic volcanic and plutonic rocks from the Putumayo region (southern Colombia): tectonic setting and regional correlations

TABLE 2. Geochronological data, Bold data were rejected from the age calculations because lead loss, mixing or inherited.

\begin{tabular}{|c|c|c|c|c|c|c|c|c|c|c|}
\hline $\begin{array}{l}\text { Zircon } \\
\text { Grains }\end{array}$ & ${ }^{238} \mathbf{U} /{ }^{206} \mathrm{~Pb}$ & $\begin{array}{l}1 \text { sigma } \\
\text { (\% error) }\end{array}$ & ${ }^{207} \mathrm{~Pb} /{ }^{206} \mathrm{~Pb}$ & $\begin{array}{l}1 \text { sigma } \\
\text { (\% error) }\end{array}$ & 206/238 Age & $\begin{array}{c}1 \text { sigma } \\
\text { (abs error) }\end{array}$ & $207 / 206$ age & $\begin{array}{c}1 \text { sigma } \\
\text { (abs err) }\end{array}$ & Best age & $\begin{array}{c}1 \text { sigma } \\
\text { (abs err) }\end{array}$ \\
\hline SZH121_21 & 400.721 & $2.89 \%$ & 0.0525 & $1.39 \%$ & 158.2 & 4.5 & 308.2 & 31.3 & 158.2 & 4.5 \\
\hline SZH121_9 & 366.588 & $2.24 \%$ & 0.049 & $2.16 \%$ & 173.6 & 3.8 & 149.5 & 49.8 & 173.6 & 3.8 \\
\hline SZH121_34 & 364.836 & $2.52 \%$ & 0.0514 & $1.64 \%$ & 173.9 & 4.3 & 260.5 & 37.2 & 173.9 & 4.3 \\
\hline SZH121_32 & 358.614 & $2.45 \%$ & 0.0498 & $1.34 \%$ & 177.3 & 4.3 & 183.5 & 31 & 177.3 & 4.3 \\
\hline SZH121_31 & 355.862 & $2.35 \%$ & 0.049 & $0.76 \%$ & 178.8 & 4.1 & 150 & 17.7 & 178.8 & 4.1 \\
\hline SZH121_16 & 355.261 & $2.45 \%$ & 0.0507 & $1.35 \%$ & 178.7 & 4.3 & 226.8 & 30.8 & 178.7 & 4.3 \\
\hline SZH121_12 & 353.162 & $2.06 \%$ & 0.0518 & $1.93 \%$ & 179.5 & 3.7 & 276.6 & 43.5 & 179.5 & 3.7 \\
\hline SZH121_29 & 352.174 & $2.45 \%$ & 0.0516 & $1.29 \%$ & 180.1 & 4.4 & 268.4 & 29.4 & 180.1 & 4.4 \\
\hline SZH121_2 & 352.124 & $1.99 \%$ & 0.0579 & $1.6 \%$ & 178.6 & 3.5 & 526.7 & 34.7 & 178.6 & 3.5 \\
\hline SZH121_28 & 351.729 & $2.47 \%$ & 0.0501 & $1.37 \%$ & 180.6 & 4.4 & 199.1 & 31.5 & 180.6 & 4.4 \\
\hline SZH121_26 & 351.408 & $2.45 \%$ & 0.0514 & $1.32 \%$ & 180.5 & 4.4 & 259.6 & 30 & 180.5 & 4.4 \\
\hline SZH121_1 & 35.095 & $1.91 \%$ & 0.0511 & $1.57 \%$ & 180.8 & 3.4 & 247.5 & 35.8 & 180.8 & 3.4 \\
\hline SZH121_10 & 350.467 & $1.89 \%$ & 0.056 & $1.54 \%$ & 179.9 & 3.4 & 452 & 33.9 & 179.9 & 3.4 \\
\hline SZH121_8 & 35.031 & $1.91 \%$ & 0.053 & $1.48 \%$ & 180.7 & 3.4 & 327.4 & 33.2 & 180.7 & 3.4 \\
\hline SZH121_30 & 349.997 & $2.44 \%$ & 0.0496 & $1.43 \%$ & 181.6 & 4.4 & 176.8 & 32.9 & 181.6 & 4.4 \\
\hline SZH121_14 & 349.874 & $1.91 \%$ & 0.0505 & $1.54 \%$ & 181.5 & 3.4 & 216.9 & 35.2 & 181.5 & 3.4 \\
\hline SZH121_25 & 34.918 & $2.49 \%$ & 0.052 & $1.31 \%$ & 181.5 & 4.5 & 285.4 & 29.8 & 181.5 & 4.5 \\
\hline SZH121_6 & 348.332 & $2.04 \%$ & 0.0545 & $1.76 \%$ & 181.4 & 3.7 & 392.1 & 39.1 & 181.4 & 3.7 \\
\hline SZH121_20 & 348.012 & $2.45 \%$ & 0.0534 & $1.38 \%$ & 181.8 & 4.4 & 347.3 & 30.9 & 181.8 & 4.4 \\
\hline SZH121_5 & 346.843 & $2.48 \%$ & 0.072 & $3.54 \%$ & 178.1 & 4.5 & 984.9 & 70.5 & 178.1 & 4.5 \\
\hline SZH121_7 & 343.893 & $1.91 \%$ & 0.0512 & $1.52 \%$ & 184.4 & 3.5 & 249.8 & 34.6 & 184.4 & 3.5 \\
\hline SZH121_23 & 34.153 & $2.4 \%$ & 0.05 & $0.91 \%$ & 186 & 4.4 & 193.2 & 21 & 186 & 4.4 \\
\hline SZH121_3 & 340.609 & $1.99 \%$ & 0.0531 & $1.59 \%$ & 185.8 & 3.7 & 332 & 35.7 & 185.8 & 3.7 \\
\hline SZH121_33 & 329.671 & $2.44 \%$ & 0.0944 & $1.65 \%$ & 181.8 & 4.6 & 1515.4 & 30.8 & 181.8 & 4.6 \\
\hline SZH121_22 & 306.908 & $2.58 \%$ & 0.077 & $2,00 \%$ & 199.7 & 5.3 & 1120.6 & 39.4 & 199.7 & 5.3 \\
\hline SZH121_18 & 269.557 & $3.5 \%$ & 0.0609 & $2.09 \%$ & 231.9 & 8.1 & 634 & 44.4 & 231.9 & 8.1 \\
\hline SZH121_35 & 238.519 & $2.5 \%$ & 0.0544 & $1.67 \%$ & 263.8 & 6.5 & 386.8 & 37 & 263.8 & 6.5 \\
\hline SZH121_15 & 23.456 & $1.89 \%$ & 0.0524 & $1.35 \%$ & 268.9 & 5 & 304.7 & 30.5 & 268.9 & 5 \\
\hline SZH121_24 & 228.932 & $2.61 \%$ & 0.0523 & $1.69 \%$ & 275.4 & 7 & 299.4 & 38.1 & 275.4 & 7 \\
\hline SZH121_27 & 66.925 & $2.51 \%$ & 0.0691 & $0.93 \%$ & 897.5 & 21 & 903.1 & 19.1 & 903.1 & 19.1 \\
\hline SZH121_15A & 56.571 & $2.35 \%$ & 0.0727 & $0.78 \%$ & 1051.4 & 22.7 & 1006.8 & 15.7 & 1006.8 & 15.7 \\
\hline SZH121_13 & 35.259 & $1.78 \%$ & 0.0966 & $0.94 \%$ & 1615.3 & 25.3 & 1559.1 & 17.6 & 1559.1 & 17.6 \\
\hline SZH121_11 & 36.292 & $1.77 \%$ & 0.097 & $0.94 \%$ & 1569.1 & 24.6 & 1567.1 & 17.5 & 1567.1 & 17.5 \\
\hline SZH121_19 & 247.161 & $3.15 \%$ & 0.1083 & $2.75 \%$ & 237.2 & 7.9 & 1771.4 & 49.3 & 1771.4 & 49.3 \\
\hline SZH72_25 & 338.572 & $1.88 \%$ & 0.0471 & $1.89 \%$ & 188.3 & 3.5 & 56 & 44.6 & 188.3 & 3.5 \\
\hline SZH72_24 & 345.488 & $1.73 \%$ & 0.0496 & $1.44 \%$ & 184 & 3.1 & 175 & 33.3 & 184 & 3.1 \\
\hline SZH72_22 & 345.895 & $1.58 \%$ & 0.0509 & $1.22 \%$ & 183.5 & 2.9 & 236.9 & 27.9 & 183.5 & 2.9 \\
\hline SZH72_21 & 340.813 & $1.83 \%$ & 0.0494 & $1.62 \%$ & 186.5 & 3.4 & 167.9 & 37.5 & 186.5 & 3.4 \\
\hline SZH72_20 & 339.901 & $1.7 \%$ & 0.0523 & $1.33 \%$ & 186.3 & 3.1 & 298 & 30 & 186.3 & 3.1 \\
\hline SZH72_19 & 333.108 & $1.8 \%$ & 0.0517 & $1.75 \%$ & 190.2 & 3.4 & 273.4 & 39.6 & 190.2 & 3.4 \\
\hline SZH72_17 & 352.476 & $1.69 \%$ & 0.0521 & $1.53 \%$ & 179.8 & 3 & 288.9 & 34.7 & 179.8 & 3 \\
\hline SZH72_16 & 329.257 & $1.76 \%$ & 0.0642 & $1.99 \%$ & 189.4 & 3.3 & 747.6 & 41.5 & 189.4 & 3.3 \\
\hline SZH72_15 & 334.619 & $1.95 \%$ & 0.0816 & $1.63 \%$ & 182.2 & 3.6 & 1235.3 & 31.6 & 182.2 & 3.6 \\
\hline SZH72_14 & 343.783 & $1.86 \%$ & 0.0531 & $1.84 \%$ & 184.1 & 3.4 & 331.4 & 41.2 & 184.1 & 3.4 \\
\hline SZH72_13 & 345.701 & $1.75 \%$ & 0.0499 & $1.26 \%$ & 183.8 & 3.2 & 190.4 & 29.2 & 183.8 & 3.2 \\
\hline SZH72_11 & 337.238 & $1.79 \%$ & 0.0541 & $1.57 \%$ & 187.4 & 3.3 & 376.4 & 35 & 187.4 & 3.3 \\
\hline SZH72_10 & 327.592 & $1.93 \%$ & 0.0642 & $2.11 \%$ & 190.4 & 3.7 & 747.1 & 44 & 190.4 & 3.7 \\
\hline SZH72_9 & 33.964 & $1.88 \%$ & 0.0504 & $1.55 \%$ & 186.9 & 3.5 & 215.7 & 35.6 & 186.9 & 3.5 \\
\hline SZH72_8 & 342.151 & $1.86 \%$ & 0.0501 & $1.48 \%$ & 185.6 & 3.4 & 198.5 & 34 & 185.6 & 3.4 \\
\hline SZH72_6 & 333.333 & $1.95 \%$ & 0.0581 & $1.86 \%$ & 188.6 & 3.7 & 534.8 & 40.1 & 188.6 & 3.7 \\
\hline SZH72_5 & 339.443 & $2.01 \%$ & 0.0537 & $1.8 \%$ & 186.3 & 3.7 & 357.8 & 40.1 & 186.3 & 3.7 \\
\hline SZH72_4 & 336.761 & $1.84 \%$ & 0.05 & $1.62 \%$ & 188.6 & 3.4 & 193.2 & 37.2 & 188.6 & 3.4 \\
\hline SZH72_3 & 329.673 & $1.8 \%$ & 0.0742 & $1.42 \%$ & 186.7 & 3.4 & 1048 & 28.4 & 186.7 & 3.4 \\
\hline SZH72_2 & 346.859 & $1.92 \%$ & 0.0556 & $1.56 \%$ & 181.9 & 3.5 & 436.1 & 34.3 & 181.9 & 3.5 \\
\hline SZH72_1 & 339.575 & $1.74 \%$ & 0.0503 & $1.28 \%$ & 187 & 3.2 & 210.1 & 29.3 & 187 & 3.2 \\
\hline
\end{tabular}



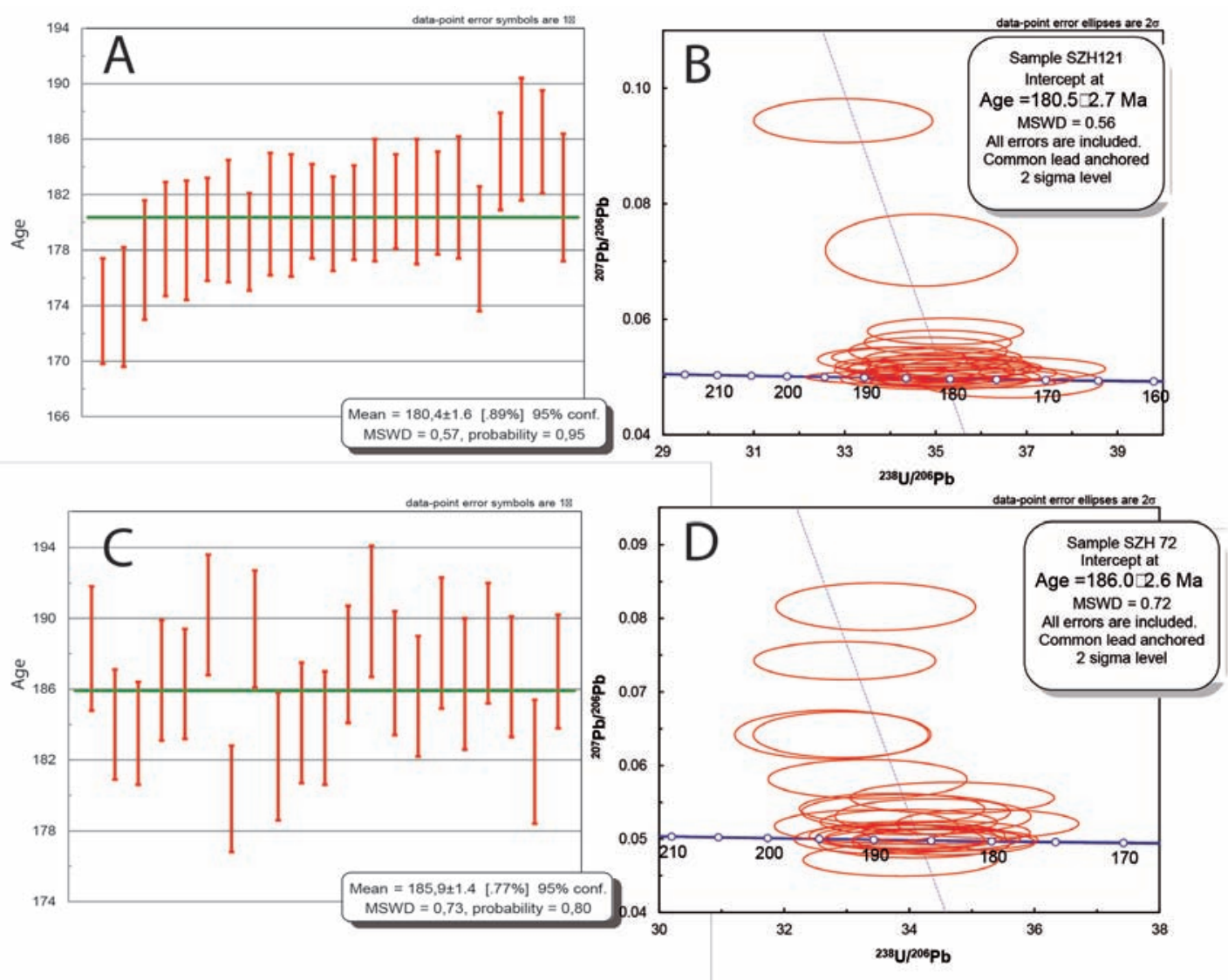

FIGURE 9. U-Pb zircon ages. A. Mocoa Batholith zircon age; B. Mocoa Batholith Tera-Wasserburg diagram; C. Saldaña Formation tuff zircon age; D. Saldaña Formation Tera-Wasserburg diagram.

\section{DISCUSSION}

Field relations, geochronological and geochemical data show that the Saldaña Formation and Mocoa Batolith in southern Colombia are spatially, temporally and genetically related to a common Middle Jurassic magmatism between 186-180 Ma.

The compositional diversity of the Saldaña Formation varying from basalt to rhyolite and the well-defined correlation in major element bivariate trends are consistent with a typical pattern of differentiation processes of cogenetic igneous systems. The younger crystallization age of the Mocoa Batholith and its intrusive relation in the Saldaña Formation is also a common pattern of related volcano-plutonic systems where the intrusive record the later phases of the magmatic evolution (Lipman, 2007).

Trace element concentrations show relative enrichment of LILE and LREE compared with HREE, negative anomalies of $\mathrm{Nb}$ and $\mathrm{Ti}$ as well as $\mathrm{Ta} / \mathrm{Hf}$ ratios, is characteristic of a continental magmatic arc tectonic setting (Harris et al., 1986; Pearce et al., 1984; Schandl and Gorton, 2002; Wood, 1980). High Pb is associated to the involvement of the continental crust during magma genesis, either as assimilated or as source component (Miller and Christensen, 1994).

Similar U-Pb magmatic crystallization ages and arc related magmatic affinity have been reported in plutonic rocks in the adjacent Garzón Massif and Upper Magdalena Valley (Bustamante et al., 2010) or in the eastern flank of the Central Cordillera (Altenberger and Concha, 2005). Together with other Jurassic exposures in the Ecuadorian Andes (Chiaradia et al., 2009), this suggests the existence of a regional scale contemporaneous arc magmatic history.

Early-Middle Jurassic (180-200 Ma) magmatic rocks also have been found in other segments of the Colombian Andes (FIGURE 1), including the Santander and Santa Marta massifs (Altenberger and Concha, 2005; Cardona et al., 2011), and are also common along most of the Andean Chain (Mpodozis and Ramos, 2008; Vásquez et al., 2011) 
Although some of the Jurassic remnants in the Colombian Andes may have been displaced from southern latitudes (Bayona et al., 2006), the existence of a major Jurassic continental scale magmatic province and its apparent link with extensional basins (Mpodozis and Ramos, 2008; Sarmiento et al., 2006; Vásquez et al., 2011) reflect the plate convergence following Pangea break-up, and the subduction of an old Pacific plate that controlled the growth of a continental magmatic arc and the contemporaneous regional scale magmatic activity (Busby, 2012; Cawood and Buchan, 2007; Cawood et al., 2009).

\section{ACKNOWLEDGMENTS}

We acknowledge the Smithsonian Tropical Research Institute (STRI) for its support during several phases of the project. G. Bayona, M. Weber M. and C. Echeverri are acknowledged for their discussions and continuous support and the reviewers who helped to improve the article. S. Zapata acknowledges COLCIENCIAS for a young researchers fellowship. E. Maya and Sibundoy authorities are acknowledged for their support during field work. G. Cañizález is acknowledged for its help with sample preparation.

\section{REFERENCES}

Altenberger, U., and Concha, A.E. 2005. Late lower to early Middle Jurassic arc magmatism in the northern Ibagué Batholith (Colombia). Geología Colombiana, 30: 87-97.

Álvarez, J., 1979. Geología de la Cordillera Central y el Occidente Colombiano y petroquímica de los intrusivos granitoides mesocenozoicos, Tesis de doctorado, Universidad de Chile, Santiago de Chile, 359p.

Amaya, C., y Centenaro, J. 1997. Ambiente deposicional y modelamiento del Yacimiento Caballos en el Campo Orito, Cuenca Putumayo. VI Simposio Bolivariano Exploracion Petrolera en las Cuencas Subandinas, Vol. 2, Colombia, pp. 30 - 33.

Aspden, J.A., McCourt, W.J., and Brook, M. 1987. Geometrical control of subduction-related magmatism: the Mesozoic and Cenozoic plutonic history of Western Colombia. Journal of the Geological Society, 144: 893-905.

Ayala, R.C., Bayona, G., Cardona, A., Ojeda, C., Montenegro, O.C., Montes, C., Valencia, V., and Jaramillo, C. 2012. The Paleogene synorogenic succession in the northwestern Maracaibo block: tracking intraplate uplifts and changes in sediment delivery systems. Journal of South American Earth Sciences, 39: 93-11.

Bas, M.J.L., Maitre, R.W.L., Streckeisen, A., and Zanettin, B. 1986. A Chemical classification of volcanic rocks based on the total alkali-silica diagram. Journal of Petrology, 27: 745-750.

Bayona, G. 1994. Litoestratigrafia de la Formacion Saldaña. En: Estudios Geológicos del Valle Superior del Magdalena, Universidad Nacional de Colombia, Bogota, pp. 21.

Bayona, G., Jimenez, G., Silva, C.A., Cardona, A., Montes, C., Roncancio, G., and Cordani, U. 2010. Paleomagnetic data and $\mathrm{K}-\mathrm{Ar}$ ages from Mesozoic units of the Santa Marta massif: a preliminary interpretation for block rotation and translations. Journal of South American Earth Sciences, 29: 817-831.

Bayona, G., Rapalini, A., and Costanzo-Alvarez, V., 2006. Paleomagnetism in Mesozoic rocks of the Northern Andes and its implications in Mesozoic tectonics of northwestern South America. Earth Planets and Space, 58: 1255-1272.

Boschman, L.M., van Hinsbergen, D.J.J., Torsvik, T.H., Spakman, W., and Pindel, J.L. 2014. Kinematic reconstruction of the Caribbean region since the Early Jurassic. Earth-Science Reviews, 138: 102-136.

Busby, C. 2012. Extensional and transtensional continental arc basins: case studies from the southwestern U.S. and Mexico. In: Tectonics of sedimentary basins: recent advances (Busby, C., and Azor, A., Editors). Blackwell Publishing Ltd. Chapter 19, pp. 382-404.

Bustamante, C., Cardona, A., Bayona, G., Mora, A., Valencia, V., Gehrels, G., and Vervoort, J. 2010. U-Pb LA-ICP-MS geochronology and regional correlation of Middle Jurassic intrusive rocks from the Garzon massif, Upper Magdalena Valley and Central Cordillera, Southern Colombia. Boletín de Geología, 32: 93-105.

Cardona, A., Cordani, U., and Macdonald, W. 2006. Tectonic correlations of pre-Mesozoic crust from the northern termination of the Colombian Andes, Caribbean region. Journal of South American Earth Sciences, 21: 337-354.

Cardona, A., Valencia, V., Bayona, G., Duque, J., Ducea, M., Gerherls, G., Jaramillo, C., Montes, C., Ojeda, G., and Ruiz, J. 2011. Early-subduction-related orogeny in the northern Andes: Turonian to Eocene magmatic 
and provenance record in the Santa Marta Massif and Rancheria Basin, northern Colombia. Terra Nova, 23 (1): 26-34.

Cawood, P.A., and Buchan, C. 2007. Linking accretionary orogenesis with supercontinent assembly. Earth Science Reviews, 82: 217-256.

Cawood, P.A., Kroner, A., Collins, W.J., Kusky, T.M., Mooney, W.M., and Windley, B.F 2009. Accretionary orogens through Earth history. Geological Society of London, Special Publications, 318: 1-36.

Cediel, F., and Cáceres, C. 2000. Geological Map of Colombia. Third Edition. Geotec Ltd., Bogota.

Cediel, F., Shaw, R., and Caceres, C. 2003. Tectonic Assembly of the Northern Andean block, in The Circum-Gulf of Mexico and the Caribbean: hydrocarbon habitats, basin formation and plate tectonics. AAPG Bulletin, 79: 815-848.

Chang, Z., Vervoort, J.D., McClelland, W.C., and Knaak, C. 2006. U-Pb dating of zircon by LA-ICP-MS. Geochemistry, Geophysics, Geosystems, 7 (5): 1-14.

Chiaradia, M., Vallance, J., Fontboté, L., Stein, H., Schaltegger, U., Coder, J., Richards, J., Villeneuve, M., and Gendall, I. 2009. U-Pb, Re-Os, and 40Ar/39Ar geochronology of the Nambija Au-skarn and Pangui porphyry $\mathrm{Cu}$ deposits, Ecuador: implications for the Jurassic metallogenic belt of the Northern Andes. Mineralium Deposita, 44 (4): 371-387.

Cochrane, R., Spikings, R., Gerdes, A., Winkler, W., Ulianov , A., Mora, A., and Chiaradia, M. 2014. Distinguishing between in-situ and accretionary growth of continents along active margins. Lithos 202-203: 382-394.

Cox, K.G., Bell, J.D., and Pankhurst, R.J. 1979. The interpretation of igneous rocks, London. Springer, 450p.

DeGraaff-Surpless, K., Graham, SA., Wooden, J.L., and MacWilliams, M.O. 2002. Detrital zircon provenance analysis of the Great Valley Group, California: evolution of an arc-forearc system. Geological Society of America Bulletin, 114 (12): 1564-1580.

Dickinson, W.R., and Gehrels, G., 2003. U-Pb ages of detrital zircons from Permian and Jurassic eolian sandstones of the Colorado Plateau, USA: paleogeographic implications. Sedimentary Geology, 163: 29-66.
Eggins, S.M., Kinsley, L.P.J., and Shelley, J.M.G. 1998. Deposition and element fractionation processes during atmospheric pressure laser sampling for analysis by ICP-MS Applied Surface Science, 127: 278-286.

Escalona, A., and Mann, P. 2010. Tectonics, basin subsidence mechanisms, and paleogeography of the Caribbean-South American plate boundary zone. Marine Petroleum Geology, 28: 8-39.

Goldsmith, R., Marvin, R., and Mehenert, H. 1971. Radiometric ages in the Santander Massif Eastern Colombia, Colombian Andes. United States Geological Survey, 750: 9-44.

Harris, N.W., Pearce, J.A., and Tindle, A.G. 1986. Geochemical characteristics of collision-zone magmatism. Geological Society of London, Special Publication., 19: 67-81.

Jaillard, E., Soler, P., and Cordani, U. 1990. Geodynamic evolution of the northern and central Andes during early to middle Mesozoic times: a Tethyan model. Journal of the Geological Society, London, 147: 1009-1022.

Jaramillo, L., Escovar, R., y Vesga, C.J. 1980. Edades $\mathrm{K} / \mathrm{Ar}$ en rocas con alteración hidrotermal asociadas al sistema de pórfido de cobre y molibdeno de Mocoa, Intendencia del Putumayo, Colombia. Geologia Norandina, 1: 11-18.

Kerr, A.C., Tarney, J., Marriner, G.F., Nivia, A., klaver, G.T., and Saunders, A.D. 1996. The geochemistry and tectonic setting of late Cretaceous Caribbean and Colombian. Journal of South American Earth Sciences, 9: 111-120.

Kosler, J., and Sylvester, P. 2003. Present trends and the future of zircon in geochronology: laser ablation ICPMS. Reviews in Mineralogy \& Geochemestry, 53: 243-275.

Lipman, P.W. 2007. Incremental assembly and prolonged consolidation of Cordilleran magma chambers: evidence from the Southern Rocky Mountain volcanic field. Geosphere, 3 (1): 42 - 70.

Ludwig, K.C. 2007. User's Manual For Isoplot 3.7. Berkley Geochronology Center, Berkley.

MacDonald, W., 1964. Geology of Serrania de Macuira area, Guajira Peninsula, Colombia. Ph.D. Thesis. Princeton University, New Jersey, 167p. 
McDougall, I., and Harrison, T.M. 1999. Geochronology and Thermochronology by the 40Ar/39Ar Method. Oxford Univ. Press, New York. 288p.

Mantilla, L.C., Bissig, T., Valencia, V. and Hart, C.J.R., 2013. The magmatic history of the Vetas-California mining district, Santander Massif, Eastern Cordillera, Colombia. Journal of South American Earth Sciences, 45: 235-249.

Marquínez, G. and Velandia, F., 2001. Mapa geológico del departamento del Huila. Escala 1:300.000. INGEOMINAS.

McCourt, W.J., Feininger, T., and Brook, M. 1984. New geological and geochronological data from the Colombian Andes: continental growth by multiple accretion. Journal of South American Earth Sciences, 141: 831-845.

Meschede, M., and Frisch, W. 1998. Tectonic model for the Mesozoic and early Cenozoic history of the Caribbean Plate. Tectonophysics, 296: 269-291.

Miller, D.J., and Christensen, N., 1994, Seismic signature and geochemistry of an island arc: a multidisciplinary study of the Kohistan accreted terrane, Northern Pakistan. Journal of Geophysical Research, 99: 11623-11642.

Montes, C., Guzman, G., Bayona, G., Cardona, A., Valencia, V., and Jaramillo, C. 2010. Clockwise rotation of the Santa Marta Massif and simultaneous Paleogene to Neogene deformation of the Plato-San Jorge and Cesar-Ranchería basins. Journal of South American Earth Sciences, 29: 832-848.

Mora, J.A., Venegas, D., y Vergara, L. 1998. Estratigrafía del Cretácico Superior y Terciario inferior de la cuenca del Putumayo, departamento del Caquetá Colombia. Geologia Colombiana, 23: 31-65.

Mora, A., Gaona, T., Kley, J., Montoya, D., Parra, M., Quiroz, L., Reyes, G., and Strecker, M. 2009. The Role of inherited extensional fault segmentation and linkage in contractional orogenesis: a reconstruction of Lower Cretaceous inverted rift basins in the Eastern Cordillera of Colombia. Basin Research, 21: 111-137.

Mpodozis, C., and Ramos, V. 2008. Tectonica Jurásica En Argentina y Chile: extension, subduccion oblicua, rifting, reriva y colisiones?. Revista de la Asociacion Geologica Argentina, 63: 481-497.
Murcia, L.A., and Cepeda, H. 1983. Estudio geológico del Complejo Migmatítico de la Cocha - Río Téllez. IINGEOMINAS, Informe interno, 15.

Murcia, L.A. and Pichler, H., 1987. Geoquímica y dataciones radiometricas de las ignimbritas cenozoicas del SW de Colombia. Memorias del Simposio Internacional sobre Neotectónica y Riesgo Volcánicos, 2(1-3): 346-363.

Nakamura, N. 1974. Determination of REE, Ba, Fe, $\mathrm{Mg}$, Na and $\mathrm{K}$ in carbonaceous and ordinary chondrites. Geochimica et Cosmochimica Acta, 38: 757-775.

Núñez, A. 2003. Reconocimiento Geológico Regional de las Planchas 411 La Cruz, 412 San Juan De Villalobos, 430 Mocoa, 431 Piamonte, 448 Monopamba, 449 Orito Y 465 Churuyaco departamentos de Caquetá, Cauca, Huila, Nariño y Putumayo. INGEOMINAS, Bogota.

Ordóñez-Carmona, O., and Pimentel, M.M. 2002. Rb$\mathrm{Sr}$ and $\mathrm{Sm}-\mathrm{Nd}$ isotopic study of the Puquí complex, Colombian Andes. Journal of South American Earth Sciences, 15: 173-182.

Paces, J.B., and Miller, J.D. 1993. Precise U-Pb ages of Duluth Complex and related maficintrusions, northeastern Minnesota: Geochronological insights to physical, petrogenetic, paleomagnetic, and tectonomagmatic process associated with the $1.1 \mathrm{Ga}$ Midcontinent Rift System. Journal of Geophysical Research, 98: 13997-14013.

Pearce, J.A., Harris, N.W., and Tindle, A.G. 1984. Trace element discrimination diagrams for the tectonic interpretation of granitic rocks. Journal of Petrology, 25: 956-983.

Peccerillo, A., and Taylor, T.S. 1976. Geochemistry of Eocene calc-alkaline volcanic rocks from Kastamonu area, Northern Turkey. Contributions to Mineralogy and Petrology, 58: 63-81.

Pindell, J., and Dewey, J.F. 1982. Permo-Triassic reconstruction of western Pangaea and the evolution of the Gulf of Mexico-Caribbean region. Tectonics, 1: 179-211.

Pindell, J., and Erikson, J. 1993. The Mesozoic margin of northern South America. In: Salfity, J. (Ed.), Cretaceous tectonics of the Andes. Vieweg Germany, pp. 1-60.

Pindell, I.L., and Tabbutt, K.D. 1995. MesozoicCenozoic Andean paleogeography and regional controls on hydrocarbon systems. AAPG Bulletin, 62: 101-128. 
Pindell, I.L., Cande, S.C., Pitman, W.C., Rowley, D.B. Dewey, J.F, Labreeque, J., and Haxby W. 1998. A plate kinematic framework for models of Caribbean evolution. Tectonophysics, 155: 121-138.

Pindell, I.L., Kenan, L., Maresch, W.V., Stanek, K.P., Draper, G., and Higgs, R. 2005. Plate kinematic and crustal dynamics of circum-Caribbean arc-continent interactions: tectonic controls on basin development in the Proto-Caribbean margins. Geological Society of America Bulletin, 394 (Special Paper): 7-52.

Ponce, A. 1979. Anotaciones sobre geología de la parte SE del departamento de Nariño. INGEOMINAS, Informe 1769, 53.

Restrepo, J.J., and Toussaint, J.F. 1991. Terranes and continental acretion in the Colombian Andes. Episodes, 11(3): 189-193.

Ross, M.I., and Scotese, C.R. 1988. A hierarchical tectonic model of the Gulf of Mexico and Caribbean region. Tectonophysics, 155: 139-168.

Sarmiento, L.F., Van Wess, L.D., and Cloetingh, S. 2006. Mesozoic transtensional basin history of the Eastern Cordillera, Colombian Andes: inferences from tectonic models. Journal of South American Earth Sciences, 21: 383-411.

Schandl, S.J., and Gorton, M.P. 2002. Application of high field strength elements to discriminate tectonic settings in VMS environments. Economic Geology, 97: 629-642.

Shuster, D.L., and Farley, K.A. 2009. The influence of artificial radiation damage and thermal annealing on helium diffusion kinetics in apatite. Geochimica et Cosmochimica Acta, 73 (1): 183-196.

Sillitoe, R.H., Jaramillo, L., Damon, P.E., Shafiqullah, M., and Escovar, R. 1982. Setting, characteristics, and age of the andean porphyry copper belt in Colombia. Economic Geology, 77: 1837-1850.

Sisson, T.W. and Grove, T.L., 1993. Experimental investigations of the role of $\mathrm{H} 2 \mathrm{O}$ in calc-alkaline differentiation and subduction zone magmatism Contributions to Mineralogy and Petrology, 113, 143-166.

Spikings, R., Cochrane, R., Villagómez, D., Van der Lelij, R., Vallejo, C., Winkler, W., and Beate, B. 2014. The geological history of northwestern South America: from Pangaea to the early collision of the Caribbean Large Igneous Province (290-75 Ma). Gondwana Research, 27: 95-139.

Spikings, R., Winkler, W., Hughes, R.A., and Handler, R. 2005. Thermochronology of allochthonous terranes in Ecuador: unraveling the accretionary and postaccretionary history of the Northern Andes. Tectonophysics, 399: 195-220.

Sun, S.S., and McDonough, W.F. 1989. Chemical and isotopic systematics of oceanic basalts: implications for mantle composition and processes. Geological Society of London, Special Publication, 42: 313-345.

Taboada, A., Rivera, L.A., Fuenzalida, A., Cisternas, A., Philip, H., Bijwaard, H. and Olaya, J. 2000. Geodynamics of the Norther Andes: subduction and intracontinental deformation. Tectonics, 19: 787-813.

Toussaint, J.F., 1995. Evolución geológica de Colombia. Triásico - Jurásico. Ed. Universidad Nacional de Colombia, Medellin, 94p.

Toussaint, J.F. and Restrepo, J.J., 1996. Evolucion Geologica de Colombia. Cretacico. Ed. Universidad Nacional de Colombia, Medellín, 277p.

Tschanz, C., Marvin, R., Cruz, J., Mehnert, H., and Cebula, G.1974. Geologic evolution of the Sierra Nevada de Santa Marta, northeastern Colombia. Geological Society of America Bulletin, 85: 273-284.

Van der Lelij, R., Spikings, R., Ulianov, A., Chiaradia, M., and Mora, A., 2015. Palaeozoic to Early Jurassic history of the northwestern corner of Gondwana, and implications for the evolution of the Iapetus, Rheic and Pacific Oceans. Gondwana Research. doi.org/10.1016/j. gr.2015.01.011.

Vásquez, P., Glodny, J., Franz, G., Frei, D., and Romer, R. 2011. Early Mesozoic plutonism of the Cordillera de la Costa $\left(34^{\circ}-37^{\circ} \mathrm{S}\right)$, Chile: constraints on the onset of the Andean orogeny. The Journal of Geology, 119: 159-184.

Villagómez, D., Spikings, R., Magna, T., Kammer, A., Winkler, W., and Beltrán, A. 2011. Geochronology, geochemistry and tectonic evolution of the Western and Central cordilleras of Colombia. Lithos, 125: 875-896.

Villagómez, D., and Spikings, R. 2013. Thermochronology and tectonics of the Central and Western Cordilleras of Colombia: Early CretaceousTertiary evolution of the Northern Andes. Lithos, 160161: 228-249. 
Vinasco, C.J., Cordani, U.G., González, H., Wever, M., and Peláez, C. 2006. Geochronological, isotopic, geochemical data from Permo-Triassic granitic gneisses and granitoids of the Colombian Central Andes. Journal of South American Earth Sciences, 21: 355-371.

Widemann, J., and Mojica, J., 1980. Obertrias Amoniten der Saldana Formation. Tolima-Kolumbien Geowiss. Lateinam. Kolloquium. Heidelberg, 45p.

Williams, I.S., 1998. U-Th-Pb geochronology by ion microprobe. In: McKibben, M.A.; Shanks III, W.C.; Ridley, W.I.; (Editors), Applications of microanalytical techniques to understanding mineralizing processes, Reviews in Economic Geology 7: 1-35.

Wood, D.A., 1980. The application of a Th-Hf-Ta diagram to problems of tectonomagmatic classification and to establishing the nature of crustal contamination of basaltic lavasof the British Tertiary volcanic province. Earth and Planetary Science Letters, 50: 11-30.

Received: 29 May 2015

Accepted: 6 November 2015

Manuscript published online: 23 November 2015 